Portland State University

PDXScholar

\title{
Coastal Eolian Sand-Ramp Development Related to Paleo-Sea-Level Changes during the Latest Pleistocene and Holocene (21-0 ka) in San Miguel Island, California, U.S.A.
}

Curt D. Peterson

Portland State University, curt.d.peterson@gmail.com

Jon M. Erlandson

University of Oregon

Errol Stock

Triple-E Consultants

Steve W. Hostetler

United States Geological Survey

Pavid Mrice

Fil $\mathrm{w}$ this and additional works at: https://pdxscholar.library.pdx.edu/geology_fac Wollongong University

Part of the Geology Commons

Let us know how access to this document benefits you.

\section{Citation Details}

Curt D. Peterson, Jon M. Erlandson, Errol Stock, Steve W. Hostetler, and David M. Price (2017) Coastal Eolian Sand-Ramp Development Related to Paleo-Sea-Level Changes during the Latest Pleistocene and Holocene (21-0 ka) in San Miguel Island, California, U.S.A.. Journal of Coastal Research: Volume 33, Issue 5: pp. $1022-1037$.

This Article is brought to you for free and open access. It has been accepted for inclusion in Geology Faculty Publications and Presentations by an authorized administrator of PDXScholar. Please contact us if we can make this document more accessible: pdxscholar@pdx.edu. 


\title{
Coastal Eolian Sand-Ramp Development Related to Paleo- Sea-Level Changes during the Latest Pleistocene and Holocene (21-0 ka) in San Miguel Island, California, U.S.A.
}

\author{
Curt D. Peterson $^{\dagger *}$, Jon M. Erlandson ${ }^{\ddagger}$, Errol Stock ${ }^{\S}$, Steve W. Hostetler ${ }^{\dagger \dagger}$, and David M.
} Price $^{\text {t* }}$

$\dagger$ Geology Department

Portland State University

Portland, OR 97207, U.S.A.

${ }^{\dagger}$ United States Geological Survey

Corvallis, OR 97331, U.S.A.

\author{
Museum of Natural and Cultural History \\ University of Oregon \\ Eugene, OR 97403, U.S.A. \\ \$School of Earth and Environmental Sciences \\ Wollongong University \\ Wollongong, NSW 2522, Australia
}

${ }^{\S}$ Triple-E Consultants

Tarragindi, QLD 4142, Australia

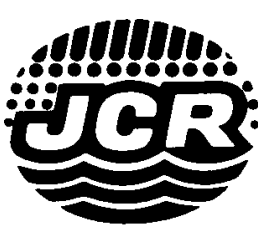

www.JCRonline.org

\begin{abstract}
Peterson, C.D.; Erlandson, J.M.; Stock, E.; Hostetler, S.W., and Price, D.M., 2017. Coastal eolian sand-ramp development related to paleo-sea-level changes during the latest Pleistocene and Holocene (21-0 ka) in San Miguel Island, California, U.S.A. Journal of Coastal Research, 33(5), 1022-1037. Coconut Creek (Florida), ISSN 0749-0208.

Coastal eolian sand ramps (5-130 m elevation) on the northern slope (windward) side of the small San Miguel Island (13 $\mathrm{km}$ in W-E length) range in age from late Pleistocene to modern time, though a major hiatus in sand-ramp growth occurred during the early Holocene marine transgression (16-9 ka). The Holocene sand ramps (1-5 m measured thicknesses) currently lack large dune forms, thereby representing deflated erosional remnants, locally covering thicker late Pleistocene sand-ramp deposits. The ramp sand was initially supplied from the adjacent island-shelf platform, extending about $20 \mathrm{~km}$ north of the present coastline. The sand-ramp deposits and interbedded loess soils were ${ }^{14} \mathrm{C}$ dated using 112 samples from 32 archaeological sites and other geologic sections. Latest Pleistocene sand ramps (66-18 ka) were derived from across-shelf eolian sand transport during marine low stands. Shoreward wave transport supplied remobilized late Pleistocene sand from the inner shelf to Holocene beaches, where dominant NW winds supplied sand to the sand ramps. The onset dates of the sand-ramp deposition in San Miguel are $7.2 \pm 1.5 \mathrm{ka}$ (sample $n=14$ ). The internal strata dates in the vertically accreting sand ramps are $3.4 \pm 1.7 \mathrm{ka}(n=34)$. The sand ramps in San Miguel show widescale termination of sand supply in the latest Holocene time. The sand-ramp top dates or burial dates are $1.7 \pm 0.9 \mathrm{ka}(n$ $=28$. The latest Holocene sand ramps are truncated along most of the island's northern coastline, indicating recent losses of nearshore sand reserves to onshore, alongshore, and, possibly, offshore sand sinks. The truncated sand ramps in San Miguel Island and in other sand-depleted marine coastlines provide warnings about future beach erosion and/or shoreline retreat from accelerated sea-level rise accompanying predicted global warming.
\end{abstract}

ADDITIONAL INDEX WORDS: Island shelf platform, paleo-wind and wave climate, coastal erosion, coastal archaeology.

\section{INTRODUCTION}

The small semi-arid San Miguel Island $\left(37 \mathrm{~km}^{2}\right)$ is located offshore of the south-central California coast (Figure 1). It provides an ideal location to establish the timing of Holocene eolian sand-ramp development on its windward slopes relative to changing sea levels under conditions of a restricted shelf sand source and modeled paleo-wave climate forcing. Many of the eolian sand ramps are erosional remnants that have become truncated at eroded shorelines, thereby separating them from their previous sources of beach sand supply. Most of the present sand ramps show variable stages of deflation, gullying, and/or slope failure. The sand ramps on the windward slopes of San Miguel are not characterized by large positiverelief dune forms, such as transverse, parabolic, or linear dune ridges; however, such features might have existed earlier in the

DOI: 10.2112 /JCOASTRES-D-16-00148.1 received 12 August 2016; accepted in revision 22 November 2016; corrected proofs received 16 January 2017; published pre-print online 29 March 2017.

*Corresponding author: curt.d.peterson@gmail.com

${ }^{\circ}$ Coastal Education and Research Foundation, Inc. 2017 sand-ramp development. Because of the lack of preserved dune forms, the sand-ramp deposit features are referred to as coastal eolian sand ramps.

Unlike the mainland dune sheet complexes in the San Francisco, Monterey, Santa Maria-San Antonio, and Los Angeles coastal areas (Cooper, 1967; Orme, 1992; Peterson et al., 2015), the source of sand to the San Miguel Island sand ramps was not influenced by mainland rivers or continental shelf sand transport (Johnson, 1972). The northern Channel Islands, including San Miguel Island, are separated from the mainland continental shelf by the Santa Barbara Basin. The depths of the Santa Barbara Basin, 200-500 m below mean sea level (MSL), exceed those of the lowest sea-level wave bases during the late Pleistocene time (Flemming et al., 1998). San Miguel sand ramps contain significant abundances $(\geq 20 \%)$ of calcium carbonate components (Johnson, 1972). The calcium carbonate components reflect calcite/aragonite sources from marine organisms that inhabited the offshore island-shelf platform, as shown for other nearby Channel Islands (Muhs et $a l ., 2009)$. Of particular significance to this study of sea-levelforced sand supply from an island-shelf platform is the 


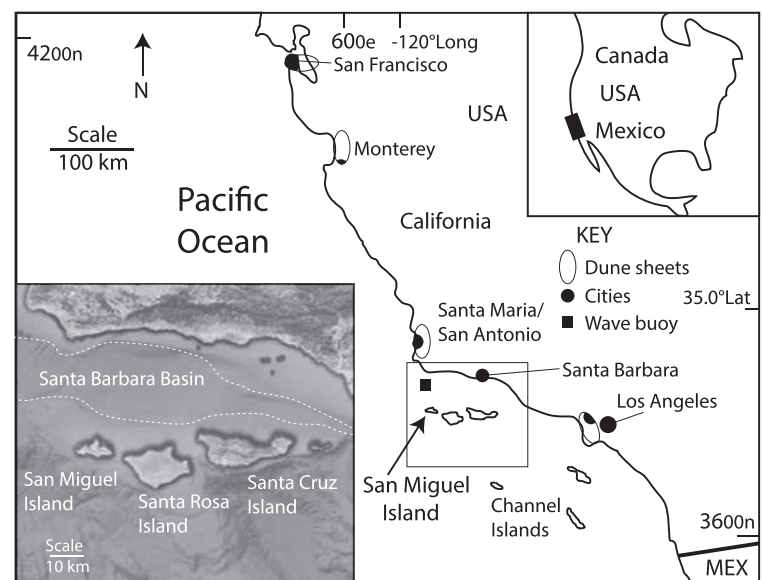

Figure 1. San Miguel Island, located offshore of the south-central California coastline, is separated from the mainland by the Santa Barbara Basin (dotted white line $>250 \mathrm{~m}$ depth below MSL). Large coastal dune sheets (stippled), cites (solid circle), and the Santa Barbara offshore wave buoy (NOAA, 2016), LLNR 198 (solid square) are shown. Unlike the large dune sheet complexes at San Francisco, Monterey, Santa Maria-San Antonio, and the Los Angeles areas, the source of sand to the isolated San Miguel Island was not influenced by mainland rivers or by mainland shelf sand supply.

extraordinary dating control of Holocene sand-ramp deposition on San Miguel Island. The timing of Holocene sand accretion on the windward (north) side of San Miguel Island is established from dated archaeological sites that are hosted in, above, and/ or below sand-ramp deposits (Erlandson, Rick, and Peterson, 2005). San Miguel Island contains one of the earliest and best preserved records of maritime Native American occupation along the western coast of North America (Erlandson et al., 1996; Erlandson et al., 2011). In this paper, the extensive records of archaeological site stratigraphy and associated radiocarbon dating of sand-ramp deposits that are available from the small San Miguel Island are utilized.

The stratigraphic records of the preserved sand ramps on the northern side of San Miguel (Figure 2) are complex, but silty paleosol marker beds and caliche paleosols are distinctive field aids for distinguishing between Holocene and late Pleistocene ages of the sand-ramp development. The latest Pleistocene sand ramps along the northern side of San Miguel Island locally overlie uplifted marine terraces (Johnson, 1972). The late Pleistocene sand ramps and associated caliche-cemented eolianite deposits from the northern side of the island are dissected by numerous gullies, exposing their stratigraphic development. Silty soil and paleosol horizons, including the Simonton-Green Mountain soils (Johnson, 1972), are locally preserved along the width and length of San Miguel Island. The distinctive soils represent low-stand loess deposits (Peterson et $a l ., 2014$ ), with the youngest loess paleosols (21-6 ka) generally separating the underlying latest Pleistocene sand-ramp deposits from the overlying Holocene sand-ramp deposits. The onset of extensive Holocene sand-ramp emplacement ( $\sim 7 \mathrm{ka})$ in San Miguel Island (Johnson, 1972) generally follows slowing of the Holocene marine transgression in middle Holocene time. Historic sand dune migration across the San Miguel hilltops

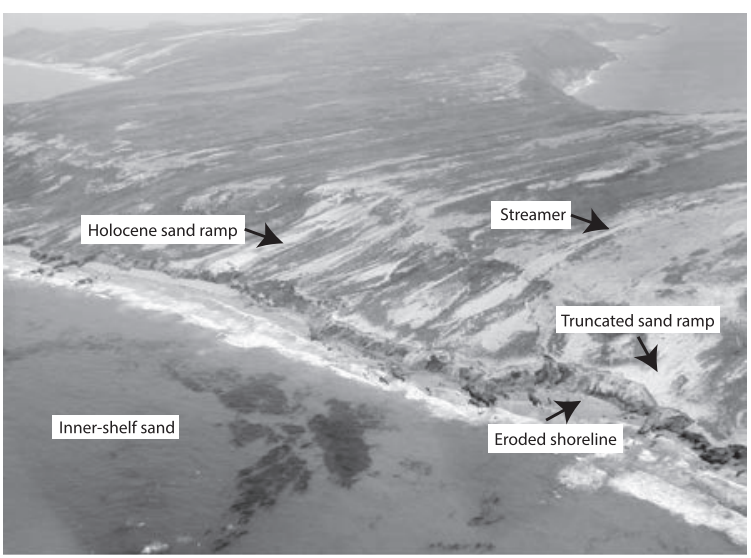

Figure 2. Oblique aerial photo of San Miguel Island's middle section; view is to the east. Holocene sand ramps are locally developed over late Pleistocene sand-ramp deposits on the northern side (windward side) of San Miguel Island (photo left). Active sand bands, or sand streamers, that cross the island from NW to SE (photo background) are partly sourced from remobilized late Pleistocene sand/dune deposits. Prevailing winds on San Miguel are from the NW (Johnson, 1972; NOAA, 2016). Both the Holocene and underlying Pleistocene sand-ramp deposits along the northern side of the island are truncated at the locally eroding coastline. Kelp-covered bedrock exposures (dark) located offshore of the retreating coastline (photo foreground) are surrounded by sand in the island inner shelf.

(mid-1900s) resulted from early historic livestock grazing and the destabilization of vegetated prehistoric sand deposit surfaces (Johnson, 1972; Rick, 2002). Stabilizing vegetation has now recolonized most of the sand-deposit surfaces, following the removal of livestock from San Miguel Island. Despite the migration of sand across San Miguel hilltops in the last century, the Holocene sand ramps on the northern side of the island are undergoing localized erosion from sea-cliff retreat, headward gullying, eolian deflation, and slope failure. In places, the gullying and slope failure of the sand ramps are mixing (1) artifacts from successive Native American occupation sites, (2) Native American artifacts with late Pleistocene faunal remains, and (3) Holocene and Pleistocene faunal remains (Erlandson, 2000; Rick, Erlandson, and Vellanoweth, 2006; Rick et al., 2009).

In this article, the timings of Holocene sand-ramp deposition, stabilization, and recent erosion are compared to changing positions and rates of the Holocene marine transgression across the small island-shelf platform, located NW of San Miguel Island (Figure 1). The dating of sand-ramp development in San Miguel Island is based on $112{ }^{14} \mathrm{C}$ dated samples, collected from 32 archaeological sites that are hosted in the sand ramps, island bluff tops, and inland hilltops (Erlandson, Rick, and Peterson, 2005). The supply of Holocene eolian sand is related to onshore transport of shelf sand deposits by W-NW storm surf, as presently reported from offshore wave buoys and as simulated in regional paleo-wind and wave stress climate models (21-0 ka time span) (Alder and Hostetler, 2015). The onset of sand-ramp erosion during the latest Holocene time is related to diminished wave transport of available shelf deposits in the deepening inner shelf and the losses of the existing beach 


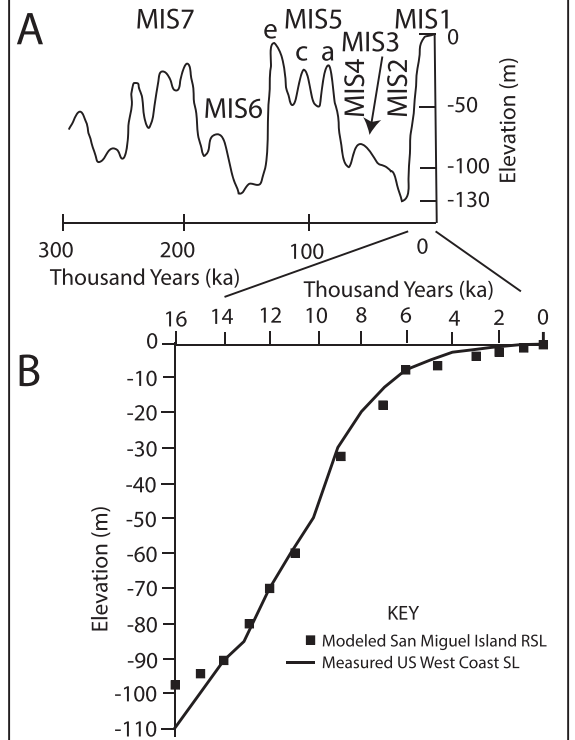

Figure 3. Part A: Eustatic sea levels varied from near present sea level at 0 $\mathrm{m}$ elevation to $-130 \mathrm{~m}$ during the last glacial maximum (LGM) at $\sim 20 \mathrm{ka}$. Sea levels during most of late Pleistocene time ranged from -50 to $-100 \mathrm{~m}$ elevation. The late Pleistocene sea-level curve was redrafted from Bard, Hamelin, and Fairbanks (1990). Part B: Relative sea level (RSL) rise is shown for the Holocene marine transgression, as recorded on the central part of the west coast of North America (solid line) (Peterson et al., 2010) and modeled for the San Miguel Island area (solid squares) (Reeder-Myers et al., 2015). Paleo-sea levels ranged from $-110 \mathrm{~m}$ to $-100 \mathrm{~m}$ elevation at $16 \mathrm{ka}$ to 0 $\mathrm{m}$ at present time. Rates of sea-level rise decreased greatly between 9 and 6 $\mathrm{ka}$

sand to upland, alongshore, and/or offshore sand sinks. With predicted future rising sea levels (Vermeer and Rahmstorf, 2009), the expected acceleration of coastal erosion could threaten numerous archaeological and paleontological sites located along the current San Miguel Island coast (Erlandson, 2008; Reeder, Rick, and Erlandson, 2011). The recent wave erosion of beach and eolian sand-ramp deposits serves as a warning about future beach erosion in other island littoral systems, following potential sea-level rise from predicted global warming (Meehl et al., 2007; Rahmstorf, 2007).

\section{Background}

Holocene dune sheet development along the central California coast has been linked to shelf sand supply from shoreward wave transport during the Holocene marine transgression (Cooper, 1967; Johnson, 1972; Knott and Eley, 2006; Orme, 1992; Peterson et al., 2015). Recent luminescence dating of the San Francisco and Monterey dune sheets (Figure 1) has demonstrated that across-shelf eolian sand supply from offshore depocenters occurred during glacial low-stand intervals (Peterson et al., 2015). This article addresses eolian sandramp development in San Miguel Island during late Pleistocene marine low stands and the Holocene marine transgression. During late Pleistocene glacial low stands, including marine isotope stages MIS2, MIS4, and MIS6, the lowest eustatic sea levels dropped to elevations of -100 to $-130 \mathrm{~m}$ (Figure 3A). During interglacial high stands (MIS1, MIS5, and

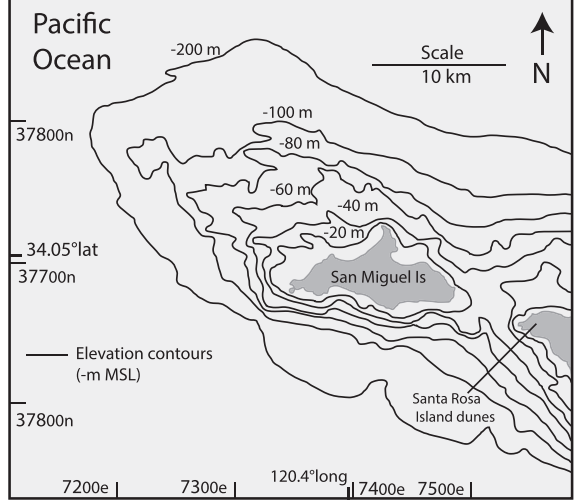

Figure 4. San Miguel Island-shelf platform with depth contours $(\mathrm{m})$ relative to modern mean sea level (MSL). See Figure 1 for the position of the San Miguel Island-shelf platform, located seaward of the Santa Barbara Basin.

MIS7), the highest eustatic sea levels approached modern sea level (Bard, Hamelin, and Fairbanks, 1990). During the Holocene transgression, the regional sea level rose from about $-110 \mathrm{~m}$ at $16 \mathrm{ka}$ to $-30 \mathrm{~m}$ at $9 \mathrm{ka}$, or a sea-level rise rate of $\sim 10$ $\mathrm{m} \mathrm{ka}{ }^{-1}$ (Figure 3B) (Clark, Mitrovica, and Alder, 2014; Peterson et al., 2010; Reeder-Myers et al., 2015). The rate of sea-level rise began to decline after $9 \mathrm{ka}$, reaching $4-5 \mathrm{~m} \mathrm{ka}^{-1}$ at $7 \mathrm{ka}$ and only $\sim 1.0 \mathrm{~m} \mathrm{ka}^{-1}$ during the latest Holocene time $(\leq 3$ ka). Future rates of relative sea-level rise could greatly increase, by as much as a factor of 10 , to reach $\sim 1 \mathrm{~m}$ above modern MSL by 2100, following predicted future global warming during this century (Grinsted, Moore, and Jevrejeva, 2010; Rahmstorf, 2010; Vermeer and Rahmstorf, 2009).

The offshore shelf platform (0-200 m water depth) located NW of San Miguel Island is $\sim 20 \mathrm{~km}$ in width and length (Figure 4). About $60 \%$ of the surface area of the island-shelf platform is less than $100 \mathrm{~m}$ in water depth. That area would have been exposed to eolian sand transport during late Pleistocene marine low stands (Figure 3A). The Holocene marine transgression submerged the shallow shelf platform from the northern, western, and eastern sides. Wave refraction would have redirected deep-water waves from the W, NW, and $\mathrm{N}$ toward the central axis of the shelf platform, transporting remobilized shelf sand toward the northern shores of San Miguel. Some of the shelf sand that bypassed San Miguel Island during latest Pleistocene and Holocene times could have supplied some of the sand in the dune fields on the northern coastline of Santa Rosa Island (Johnson, 1972; Orr, 1968), which is located SE of San Miguel Island.

San Miguel Island and Santa Rosa Island (Figures 1 and 4) experienced substantial paleo-climate changes across the late Pleistocene/Holocene transition and later vegetation changes in mid-late Holocene time, possibly attributable to humancaused fire. Archaeological and pond/pollen sites on the two small islands have been analyzed for changes in vegetation types, from $12 \mathrm{ka}$ to the present (Anderson et al., 2010; Erlandson et al., 1996; West and Erlandson, 1994). Late Pleistocene coastal conifer forests in the highlands converted to pine, sage, and grasslands by $11,800 \mathrm{cal} \mathrm{BP}$ as the climate 


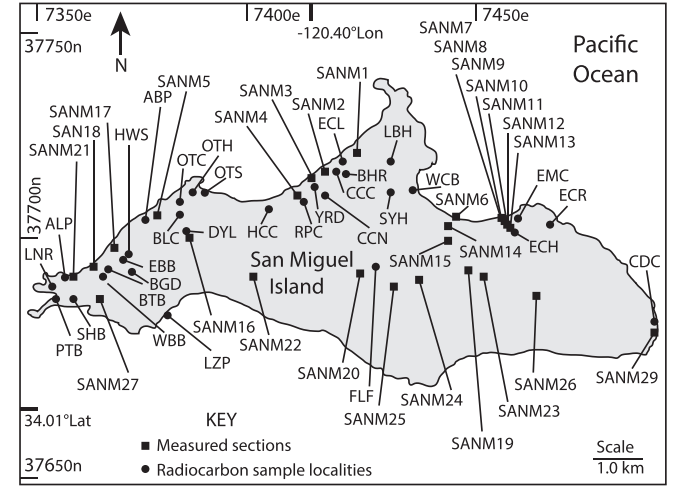

Figure 5. Location of measured sections (SANM) and ${ }^{14} \mathrm{C}$ and $\mathrm{TL}$ dated sand-ramp deposit sites (three letter abbreviations) in San Miguel Island. Details about measured section positions and radiocarbon dating laboratory analyses are provided in Erlandson, Rick, and Peterson (2005) and Peterson et al. (2006).

warmed. By 9150 cal BP, coastal sage scrub covered the hill slopes, and after $\sim 6900$ cal BP grasslands became more prevalent, possibly because of human-caused fires (Anderson et al., 2010). In summary, the warming and drying conditions of the early Holocene (prior to $9 \mathrm{ka}$ ) should have promoted eolian sand transport on San Miguel Island relative to the late Pleistocene time. As shown in this article, however, the sandramp development in San Miguel Island peaked in midHolocene time (7-4 ka), requiring a different origin/mechanism for changing sand supply to the northern (windward) slopes of the small islands.

\section{METHODS}

Shallow measured sections, 29 in number, were established in gully cuts, sea cliffs, sand-deflation troughs, and headwall scarps in Holocene and late Pleistocene sand ramps and hilltop deposits in San Miguel Island (Figure 5) (Peterson et al., 2006). The measured sections range from 2 to $27 \mathrm{~m}$ in depth below surface. The representative sections include measurements of distinctive soil and paleosol horizons, as defined by (1) grain size (AM/CAN Stratigraphic grain size cards), (2) dry color (Munsel color charts), (3) cementation (Birkeland, 1999), and (4) quantitative analyses of unconfined shear strength, as measured by penetrometer resistance $\left(\mathrm{kg} \mathrm{cm}^{-2}\right)$. Sand grain sizes are as follows: very fine lower (vfL) 6-88 $\mu \mathrm{m}$, very fine upper (vfU) 88-125 $\mu \mathrm{m}$, fine lower (fL) 125-177 $\mu \mathrm{m}$, fine upper (fU) 177-250 $\mu \mathrm{m}$, medium lower (mL) 250-350 $\mu \mathrm{m}$, and medium upper (mU) 350-500 $\mu \mathrm{m}$. Soil-profile development was calibrated against thermoluminescence (TL) and radiocarbon $\left({ }^{14} \mathrm{C}\right)$ ages of the sandramp deposits to establish soil chronosequences (Peterson et al., 2006). The soil chronosequences are used to help discriminate between late Pleistocene and Holocene ages of sand-ramp deposit emplacement in San Miguel. Details about the dating of the two TL samples from the measured sections SANM3 and SANM15 are presented in Peterson $e t$ al. (2006). The methods of compiling the sand-ramp deposit stratigraphy and ${ }^{14} \mathrm{C}$ data from archaeological site records are outlined here.

Sand layer and loess stratigraphic relations, together with corresponding ${ }^{14} \mathrm{C}$ dated samples $(n=112)$, were compiled from 32 San Miguel archaeological sites (Figure 5) (Erlandson, Rick, and Peterson, 2005). The ${ }^{14} \mathrm{C}$ samples were selected from charcoal and marine shells associated with shell middens (Erlandson and Rick, 2002) in recorded archaeological sites. The sample dates were adjusted for isotopic fractionation, and the shell dates were corrected for both global and regional marine reservoir effects. The Holocene dates were calibrated (Calib4.3) for \pm 1 standard deviation (SD) $( \pm 1 \sigma)$ uncertainties (Erlandson, Rick, and Peterson, 2005). For the purposes of this article, calibrated radiocarbon dates (cal year BP) are converted to thousands of years (ka), as rounded to 100 years $(0.1 \mathrm{ka})$. The standardized sample dates (ka) permit comparisons to published TL dates, sealevel curves, and paleo-climate records, which are all provided in ka time scales. Here, the individual sample dates are referred to as dates, and the averaged group dates are referred to as ages. Archaeological site records were reviewed to establish the vertical positions of the ${ }^{14} \mathrm{C}$ dated samples relative to eolian deposit tops, bottoms, and/or internal strata. All Holocene radiocarbon sand-ramp bottom samples were collected within $10 \mathrm{~cm}$ of the bottom sand contact. All radiocarbon sand-ramp top samples were collected to within $10 \mathrm{~cm}$ of the upper sand contact below terminal midden materials. This sample collection methodology represents the greatest stratigraphic accuracy that can be expected for subaerial granular deposits on moderately steep slopes. Potential errors in age estimates that could be associated with syndepositional mixing, time lags, and/or transported radiocarbon materials are reduced by multiple samples from multiple sites in the densely sampled San Miguel study area. The radiocarbon sample relative position data and corresponding sample radiocarbon analyses are published in Erlandson, Rick, and Peterson (2005). Summarized ${ }^{14} \mathrm{C}$ sample site names, position coordinates, elevations, stratigraphic positions, and corresponding standardized dates from San Miguel Island are presented in this article.

The relative stratigraphic positions include (1) Holocene sand-ramp top (HRT), (2) Holocene sand-ramp internal strata (HRS), (3) Holocene sand-ramp bottom (HRB), (4) Simonton soil top (SST), and (5) Simonton soil internal strata (SSS). The HRB date is from the lowest (oldest) sand layer at the site, and it constrains the onset of sand-ramp deposition at the site. The HRT date is from the youngest terminal sand layer at the site, and it represents the end of prehistoric sandramp deposition at the site. Sand-ramp surfaces that are not buried by midden materials or are still actively mixing, accreting, or transporting sand are not reported here. Multiple samples from individual sites yield ranges of dates, attributable in part to variations in radiocarbon materials and depositional processes within the site. The SST dates represent the termination of the youngest loess accumulation at the site prior to burial by eolian sand deposits and/or shell midden materials.

Spatially variable erosion of sand ramps and beach shorelines along the remote northern coast of San Miguel 


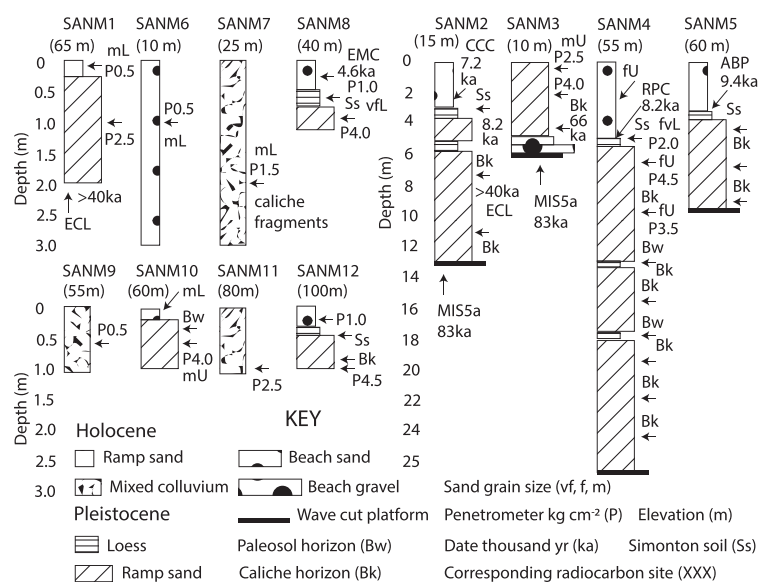

Figure 6. Measured sections of sand-ramp deposit stratigraphy are shown, generally from the NE areas of San Miguel Island. See Figure 5 for positions of measured sections and nearest ${ }^{14} \mathrm{C}$ dated sites. Measured sections include elevations (m), depth below surface $(\mathrm{m})$, sand grain size, soil profile accumulation horizons ( $\mathrm{Bw}$ and $\mathrm{Bt} / \mathrm{Bk}$ ), uppermost Simonton soil loess deposit $(\mathrm{Ss})$, penetrometer resistance $(\mathrm{P})$, and deposit dates (ka). Sand grain sizes include upper (U) and lower (L) values of very fine (vf), fine (f), and medium $(\mathrm{m})$ size sand.

have not been studied or documented. San Miguel beach access is restricted because of sensitive archaeological sites and pinniped rookery haul outs. For this study, modern satellite imagery (4 January 2015 at 1700 PST) is used to map (1) subaerial winter beach widths (swash line to sea cliff) of less than $50 \mathrm{~m}$ during a tidal stage of mean lower low water (MLLW) and (2) apparent gullies that dissect/erode Holocene sand-ramp deposits along distances of at least $100 \mathrm{~m}$ landward from the beach backshore. A 50-m-wide low-tide sand beach on a fully exposed NE Pacific Ocean coastline will permit waves to attack the sea cliff during combined major winter storm surf and high tides. Such conditions, for the purposes of this article, yield episodically erosive backshore settings.

The narrow beach widths $(<50 \mathrm{~m})$ and apparent gullying of dune ramps represent a depletion of shoreline sand supply to San Miguel's windward sand ramps. Wider beaches $(>100 \mathrm{~m}$ width) with apparent foredune development at the base of active sand ramps are also mapped from the satellite imagery. The presence of wider beaches and non-eroded sand ramps/ foredunes are assumed to represent a modern net surplus of beach sand supply. These proxies are used to differentiate episodically eroded shorelines/sand ramps from stable or accreting shorelines/sand ramps along the remote northern coast of San Miguel. Net historic shoreline retreat or accretion are not evaluated in this study.

\section{RESULTS}

In this article, measured sections of exposed coastal eolian deposits are used to compare sand-ramp and hilltop deposit composition, thickness, vertical sequences, and ${ }^{14} \mathrm{C}$ dates from representative San Miguel Island sites. Late Holocene sand ramps are also analyzed for evidence of landward headward gullying and truncation at sea cliffs, which are indicative of ongoing erosion of sand-ramp deposits in the northern coast of San Miguel.

\section{Sand-Ramp Deposit Texture, Soil Development, and Stratigraphic Sequences}

The compositions of eolian sand-ramp deposits and hilltop eolian deposits in San Miguel are established in selected measured sections (Figure 5), chosen on the bases of Quaternary deposit mapping by Johnson (1972) and archaeological site investigations by Erlandson, Rick, and Peterson (2005). The sand-ramp deposits contain fine to medium-upper size siliclastic sand $(125-500 \mu \mathrm{m})$ with minor components of carbonate sand-size fragments (Figure 6). Thin interbeds of sandy silt (loess soils) contain vFL sand $(<85 \mu \mathrm{m})$ to silt size material. The dominant grain size of the measured Holocene sand-ramp deposits is typically $\mathrm{fU}$ or medium lower $(\mathrm{mL})$ ranging from $175-350 \mu \mathrm{m}$ in apparent mean size. Late Pleistocene sand-ramp deposits are discriminated from Holocene sand-ramp deposits on the basis of relative soil profile development and cementation. Holocene sand-ramp deposits contain only thin weak B accumulation horizons (Bw) and little to no cementation. Penetrometer resistance values of Holocene sand-ramp deposits generally ranged from $0.5-2.0 \mathrm{~kg} \mathrm{~cm}^{-2}$. Late Pleistocene sand-ramp deposits are characterized by the presence of well-developed accumulation zones (Bt), usually associated with underlying carbonate caliche accumulation horizons (Bk) (Birkeland, 1999) and penetrometer resistance values $\geq 2.5 \mathrm{~kg} \mathrm{~cm}^{-2}$ (Peterson et al., 2006).

Holocene sand ramps, with measured slope gradients of 15$60 \%$, represent thin veneers over underlying late Pleistocene sand ramps (Figure 7); however, thicker Holocene sand-ramp deposits do occur from infills of pre-existing gullies and against pre-existing topographic benches in the northern hill slopes of San Miguel. The steepest Holocene sand ramps ( $\geq 70 \%$ grade) show evidence of shallow slope failure by (1) deformed crossbedding, (2) deformed paleosol horizons, and/or (3) the presence of reworked Pleistocene soil caliche fragments of gravel size in near-surface sand deposits. Pleistocene caliche fragments were either mixed with Holocene sand colluvium, as measured in SANM7, SANM9, and SANM11 (Figure 6), or were observed as float on the Holocene sand-ramp surfaces. Modern sand-ramp gradients of $\leq 35 \%$ generally do not show evidence of slope failure or downslope transport of eroded caliche fragments. Most of the low angle sand-ramp surfaces ( $\leq 35 \%$ grade) have become stabilized by late historic vegetative recolonization (Figure 2). Cemented late Pleistocene sand-ramp surfaces reach $85 \%$ grade. Some exposed caliche strata or Bk soil horizons locally exceed $170 \%$ grade $\left(60^{\circ}\right.$ slope angle). Windcarved yardang features (Johnson, 1972) are present in some gullied late Pleistocene sand-ramp deposits, demonstrating localized sand-ramp erosion by eolian deflation.

Measured Holocene sand-ramp deposits in exposed sections range from $1 \mathrm{~m}$ to $5 \mathrm{~m}$ in vertical thickness (Figures 6 and 8). Exposed late Pleistocene sand-ramp deposits reach thicknesses of 5 to $20 \mathrm{~m}$. The late Pleistocene deposit thicknesses represent minimum values unless basal beach or wave-cut terrace units were exposed. Nevertheless, the late Pleistocene sand-ramp deposits are generally much thicker, by three to five times, 


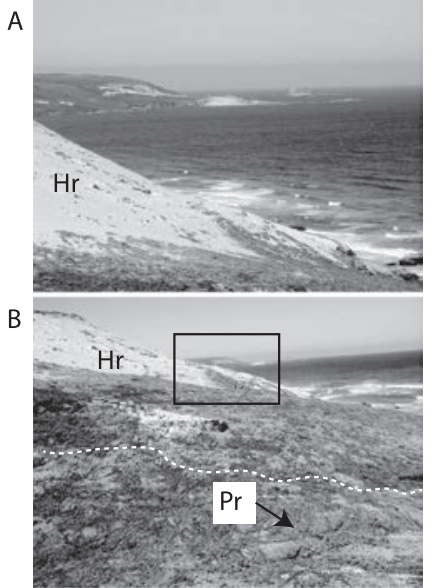

Figure 7. Part A: Photo of an active Holocene sand ramp (Hd), 6-7 ka in basal age, that climbed to $\sim 80 \mathrm{~m}$ elevation on the northern side of San Miguel Island, between measured sections SANM1 and SANM2 (Figures 5 and 6). No large-scale transverse, parabolic, or linear dune ridges occur on the deflated sand-ramp surface. The seaward base of the sand ramp is truncated and the lower slopes are being recolonized by vegetation. Part B Same profile (35\% surface gradient) of the Holocene sand ramp (box in photo background) shown from a greater distance, which demonstrates that the thin Holocene sand-ramp deposits, $(\mathrm{Hr})$ in the photo background, overlie late Pleistocene sand-ramp deposits, (Pr) in the photo foreground, as exposed in caliche cemented strata below the dashed line (white). The late Pleistocene sand-ramp deposits near SANM2 (>40 ka) (Figure 6) overlie the MIS5a marine terrace (not shown in photo).

than the overlying Holocene sand-ramp deposits. The Holocene sand-ramp deposits locally thicken at slope benches and bluff tops such as at SANM13. The greater sand-ramp thicknesses at slope benches and bluff tops are presumably attributable to

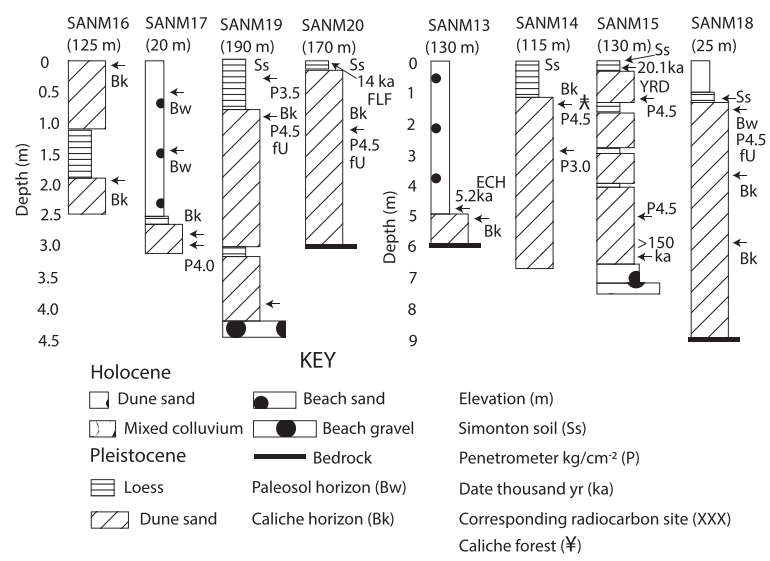

Figure 8. Measured sections of sand-ramp deposit stratigraphy are shown, generally from the NW areas of San Miguel Island. See Figure 5 for positions of measured sections and nearest ${ }^{14} \mathrm{C}$ dated archaeological sites. Measured sections include elevations $(\mathrm{m})$, depth below surface $(\mathrm{m})$, soil profile accumulation horizons ( $\mathrm{Bw}$ and $\mathrm{Bt} / \mathrm{Bk}$ ), uppermost Simonton soil loess deposit $(\mathrm{Ss})$, penetrometer resistance $(\mathrm{P})$, and deposit dates $(\mathrm{ka})$. Sand grain sizes include upper (U) and lower (L) values of very fine (vf), fine (f), and medium (m) size sand.
A

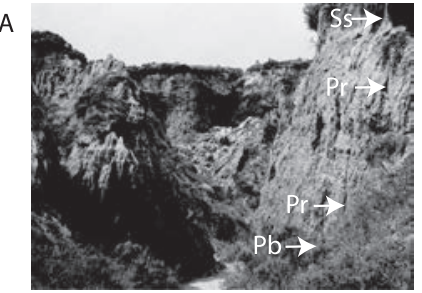

B

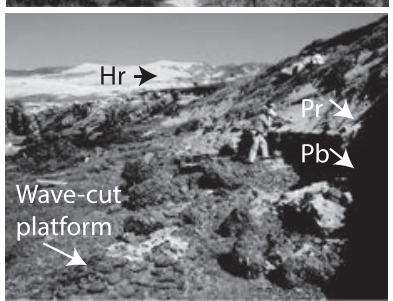

Figure 9. Part A: Photo of late Pleistocene sand-ramp deposits (Pr) and underlying beach conglomerate $(\mathrm{Pb})$ in a sand-ramp sequence $(>150 \mathrm{ka})$ near the SANM15 measured section (Figures 5 and 8). A low-stand loess layer, the Simonton soil (Ss), caps the latest Pleistocene sand-ramp deposits. View is to the south in a $\sim 15 \mathrm{~m}$ deep gully. Part B: Late Pleistocene sandramp deposits (66 ka) at SANM3 TL site (Figure 6) overlie the late Pleistocene beach sand $(\mathrm{Pb})$ and cobble conglomerate (photo foreground) from the inferred MIS5a marine terrace ( $~ 83 \mathrm{ka})$. A large Holocene sand ramp (photo upper left) overlies the late Pleistocene sand-ramp deposits that are locally exposed in the sea cliff (photo foreground).

lower slope gradients that reduce downslope sand movement, and/or detached wind flow, that permits localized sand accretion in low-velocity zones. Holocene sand ramps along the NW side of San Miguel Island (Figure 8) are generally narrower, thinner, and lower than those from the NE side of San Miguel (Figure 6). Basal dates of the Holocene sand-ramp deposits from archaeological sites near measured sections SANM2 (7.2 ka) and SANM13 (5.2 ka) are substantially younger than underlying Simonton soil loess deposits dated near SANM2 and SANM4 (8.2 ka) and SANM5 (9.4 ka).

The dated late Pleistocene sand-ramp sections range in age from $>40 \mathrm{ka}$ (SANM2) to $66 \mathrm{ka}$ (SANM3) to $>150 \mathrm{ka}$ (SANM15) (Figures 6, 8, and 9A). The TL-dated sand-ramp deposit date $(66 \pm 4 \mathrm{ka}$; Peterson et al., 2006) in the SANM3 measured section (Figure 9B) suggests that the underlying marine beach/ cobble platform at 5- to 7-m elevation is correlated to the MIS5a highstand (Figure 3A). The wave-cut terrace at SANM3 occurs at $4-5 \mathrm{~m}$ above MSL. A more prominent wave-cut terrace occurs at $10 \mathrm{~m}$ MSL along much of the NW coastline of San Miguel Island, such as at SANM18. If this low terrace correlates to the terrace at the dated SANM3 measured section, then much of the northern shoreline of San Miguel Island is backed by the MIS5a high-stand terrace at $~ 83 \mathrm{ka}$. If the lowest terrace platforms are correlated to the last major high stand (MIS5a), which reached 10-20 m below present MSL, then tectonic uplifts of $10-30 \mathrm{~m}$ in $83 \mathrm{ka}$ could translate into long-term uplift rates of $0.25-0.37 \mathrm{~m} \mathrm{ka}^{-1}$ for the northcentral coastline of San Miguel Island. Similar uplift rates have been reported for nearby Channel Islands (Muhs et al., 2012; Muhs et al., 2014; Sorlien, 1994). Additonal luminesence dating of marine terrace beach-sand deposition is needed to more 


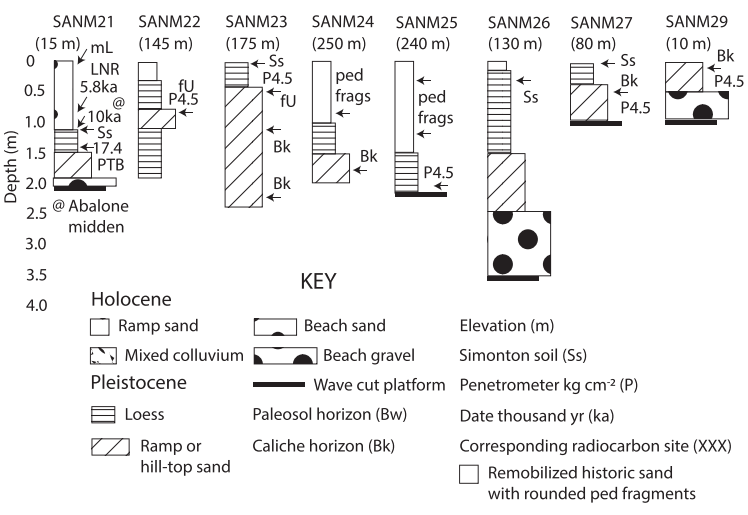

Figure 10. Measured sections of sand-ramp deposit stratigraphy are shown from the western and eastern ends of San Miguel Island and from the higher hilltop areas. See Figure 5 for positions of measured sections and nearest radiocarbon dated sites. Measured sections include elevations (m), depth below surface $(\mathrm{m})$, soil profile accumulation horizons ( $\mathrm{Bw}$ and $\mathrm{Bt} / \mathrm{Bk}$ ), uppermost Simonton soil loess deposit $(\mathrm{Ss})$, penetrometer resistance $(\mathrm{P})$, and deposit dates (ka). Sand grain sizes include upper (U) and lower (L) values of very fine (vf), fine (f), and medium (m) size sand.

firmly establish the ages of the marine terraces on San Miguel Island.

The Simonton soil loess is dated back to $\sim 18-20 \mathrm{ka}$ in site YRD (Table 1) near the measured section SANM15 (Figures 8 and 9A). This coastal loess deposit represents a marine lowstand interval (Peterson et al., 2014). If the other interbedded loess layers in measured sections SANM2, SANM4, SANM16, and SANM19 (Figures 6 and 8) represent marine low-stand intervals, then the associated sand-ramp deposits were also emplaced during marine low-stand intervals. The low-stand interval sand ramps would have been supplied by eolian transport of low-stand beach/dune deposits across the emerged island-shelf platform during late Pleistocene time (Figure 3A).

Sand deposits derived from Holocene sand ramps in the windward side of San Miguel are mostly absent from the higher hilltops at elevations of 150 to 250 (Figures 8 and 10). Only limited evidence shows that such sand migrations locally reached the southern coast of San Miguel (Braje, 2010; Braje, Erlandson, and Rick, 2013; Erlandson, Rick, and Peterson, 2005). Historically active sand streamer deposits on the hilltops were widely reactivated and locally sourced, in part from reactivated late Pleistocene and Holocene hilltop sand soils. Shallow exposures of the hilltop sand deposits were dominated by subhorizontal strata and interbedded deflation strata. The modern topography includes interconnected deflation corridors and associated linear sand ridges but rarely any parabolic dune fronts. The reactivated Pleistocene sand sources are indicated by the presence of rounded ped fragments (transported concretions) in the remobilized hilltop sand deposits. The relative contributions, if any, of Holocene sand ramps to the highest hilltop sand deposits were not resolved in this study. Loess deposits, identified as Simonton or Green Mountain soils (Johnson, 1972) cap late Pleistocene sand deposits in some hilltop sites. The terminal loess cap in measured section SANM20 is dated to $14 \mathrm{ka}$ in the nearby caliche forest site

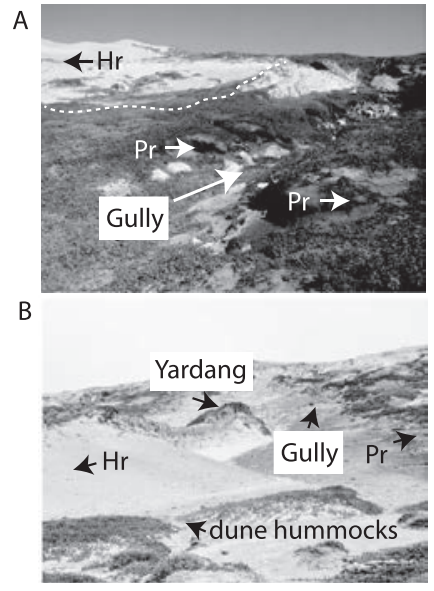

Figure 11. Part A: Photo taken upslope of the shoreline near measured section SANM3. A large Holocene sand ramp ( $\mathrm{Hr}$ ) in photo background (upper left) reaches $130 \mathrm{~m}$ elevation (top of photo) at $0.75 \mathrm{~km}$ distance landward from the shoreline. Beyond that distance the sand-ramp transitions into a narrowing sand streamer that terminates at $175 \mathrm{~m}$ elevation at $2.5 \mathrm{~km}$ landward distance from the shoreline. The Holocene sand ramp overlies late Pleistocene sand-ramp deposits $(\mathrm{Pr})$ in photo foreground, including a dark brown Bt/Bk caliche soil horizon. View is to the south. Part B: Photo taken upslope of the shoreline between measured sections SANM17 and SANM18. The small Holocene sand $\operatorname{ramp}(\mathrm{Hr})$ (photo left) is confined to a pre-existing sand gully/deflation trough that was eroded into late Pleistocene sand-ramp deposits (Pr). The gully is bounded/dissected by a wind-eroded ridge (yardang) of resistant Pleistocene ramp sand. Modern dune hummocks (mounds), as shown in the photo foreground, are becoming colonized by stabilizing vegetation (dark).

(FLF) (Figure 5) (Erlandson, Rick, and Peterson, 2005; Johnson, 1972).

The variable thicknesses of the larger Holocene sand-ramp deposits that mantle the northern slopes of San Miguel Island (Figures 6, 8, and 10) could reflect (1) localized beach sand supply, (2) localized wind transport capacity, and/or (3) localized sand-ramp deposition in slope terrace benches and bluff tops (Figure 11A). Some small Holocene sand ramps are guided upslope by pre-existing gullies and remnant late Pleistocene sand-ramp features (Figure 11B). In this study, only exposed sections from sea-cliff gully cuts and/or deflation troughs could be measured in San Miguel because of the proximity of identified archaeological sites. Pleistocene sand-deposit thicknesses reached $25 \mathrm{~m}$ in SANM18, but thicker late Pleistocene sandramp sections could occur on the northern terraced slopes of San Miguel. The thickest Holocene sand-ramp deposits that are reported in this study ( $\sim 5-\mathrm{m}$ thick) likely under-represent maximum Holocene sand-ramp thicknesses. Such maximum thicknesses, possibly up to $10 \mathrm{~m}$ thick, can be inferred from topographic mounds at some bluff-edge localities, such as upslope from SANM13 (Figure 6); however, late Pleistocene sand-ramp caliche strata, including caliche forest root/stump casts (Grimes, 2004; Johnson, 1972), locally protrude above the Holocene sand-ramp surfaces at midslope elevations (30-100 $\mathrm{m})$. The occurrences of these exposed late Pleistocene caliche strata attest to the generally thin nature of the Holocene sand ramps on the windward slopes of San Miguel. 
Table 1. Sites that provide age constraints on eolian sand ramps in San Miguel Island.

\begin{tabular}{llccr}
\hline \hline \multicolumn{1}{c}{ Site Name } & Code & UTMn & UTMe & $\begin{array}{r}\text { Elevation } \\
(\mathrm{m})\end{array}$ \\
\hline Yardang Canyon & SANM3 & 3771300 & 741270 & 10 \\
Nidever Canyon & SANM15 & 3769900 & 744180 & 130 \\
East Cuyler Harbor & ECH & 3770200 & 745500 & 60 \\
Eastmost Cuyler & EMC & 3770400 & 746000 & 30 \\
E. Cuyler Ridge & ECR & 3770300 & 746400 & 15 \\
W. Culer Beach & WCB & 3771000 & 743500 & 100 \\
Cardwell Cairn & CDC & 3768100 & 748600 & 15 \\
Sky Hill & SYH & 3770900 & 743000 & 110 \\
Liberrys Hill & LBH & 3771600 & 743000 & 100 \\
Beach Rock & BHR & 3771600 & 742000 & 75 \\
East Charcoal & ECL & 3771500 & 741800 & 60 \\
Charcoal Cove & CCC & 3771300 & 741800 & 35 \\
Charcoal Canyon & CCN & 3771000 & 741500 & 35 \\
Yardang & YRD & 3770800 & 741100 & 35 \\
Range Pole & RPC & 3770800 & 741100 & 55 \\
Hatch Cover Cove & HCC & 3770600 & 740400 & 25 \\
Otter Harbor & OTH & 3770900 & 738700 & 35 \\
Dry Lake & DYL & 3770300 & 738500 & 135 \\
H. Wash & HWS & 3769600 & 737400 & 85 \\
Otter Cave & OTC & 3770900 & 738600 & 35 \\
Bowl Cove & BLC & 3770600 & 738400 & 40 \\
Anubis Point & ABP & 3770300 & 737500 & 15 \\
Big Dune & BGD & 3769100 & 737400 & 90 \\
E. Busted Balls & EBB & 3769600 & 737100 & 35 \\
Busted Balls & BTB & 3769100 & 736700 & 35 \\
W. Busted Balls & WBB & 3769000 & 736700 & 35 \\
Abalone Point & ALP & 3769000 & 736700 & 15 \\
Lion Rocks & LNR & 3768900 & 735700 & 10 \\
Point Bennett & PTB & 3768500 & 735800 & 5 \\
South Beach & SHB & 3768600 & 736200 & 5 \\
Fossil Forest & FLF & 3769300 & 742600 & 175 \\
Leuzarder Point & LZP & 3768200 & 738300 & 10 \\
\hline & & & & \\
\hline
\end{tabular}

The TL dated sites are coded (SANM); all remaining sites (XXX) were dated by radiocarbon methods (Erlandson, Rick, and Peterson, 2005). Sample locality position coordinates (UTM 10S) northings and eastings ( $m$ ) are approximated to protect archaeological sites. Elevations are averaged for sample localities to the nearest $5 \mathrm{~m}$.

\section{Dating Sand-Ramp Deposits}

A total of 112 radiocarbon samples from 32 archaeological sites and geologic sections (Erlandson, Rick, and Peterson, 2005) and two TL samples from measured sections (SANM) are used to constrain the ages of sand-ramp development in San Miguel Island (Figure 5). The approximate location coordinates and elevations of the dated sites used in this article are presented in Table 1 . The dated eolian deposit sites range in elevation from 5 to $175 \mathrm{~m}$. Six of the sites are $\geq 100 \mathrm{~m}$ in elevation, and nine of the sites are $\leq 15 \mathrm{~m}$ in elevation. The mean and SD of site elevations are $52 \pm 43 \mathrm{~m}$, demonstrating the broad distribution of dated sand-ramp and loess soil-site elevations in San Miguel.

The relative stratigraphic positions and standardized dates (ka) of the dated samples that were used to constrain the estimated ages of the eolian deposits in San Miguel are shown in Table 2. The dated San Miguel sites include six late Pleistocene sand ramps and hilltop sand deposits, 28 HRTs, 14 HRBs, 34 HRS, six SSTs, and four Simonton soil internal or bottom strata. The HRT dates, as standardized to thousands of years (ka), range from $0.4 \mathrm{ka}$ to $3.1 \mathrm{ka}$. The HRB dates range from $5.2 \mathrm{ka}$ to $9.8 \mathrm{ka}$; however, the oldest sand-ramp bottom dates $(>9.5 \mathrm{ka})$ are all from one site: WBB. Adjacent sites EBB and BTB yield multiple constraining onset dates $(n=12)$ of $<9.0 \mathrm{ka}$, so the WBB site is considered to be an anomaly. Very early sand-ramp development $(>9.0 \mathrm{ka})$ at site WWB might represent eolian sand supply from reactivated late Pleistocene sand-ramp deposits, which was not connected to the Holocene marine transgression. More work is needed to establish the onset ages of widespread sand-ramp development in the NW end of San Miguel Island. The SST dates throughout San Miguel Island range from $11.2 \mathrm{ka}$ to $6.5 \mathrm{ka}$. Sites with multiple sample dates for the same stratigraphic positions are used to compare within-site date ranges and variability. For example, site EMC has nine HRT dates that range from $3.1 \mathrm{ka}$ to $2.4 \mathrm{ka}$ and yield a group mean and SD of $2.8 \pm 0.3 \mathrm{ka}$. Site OTH has seven HRS dates that range from $6.0 \mathrm{ka}$ to $3.2 \mathrm{ka}$ and yield a group mean and SD of $4.5 \pm 1.3 \mathrm{ka}$. Site OTC has five HRB dates that range from $6.7 \mathrm{ka}$ to $6.3 \mathrm{ka}$ and yield a group mean and SD of $6.5 \pm 0.2 \mathrm{ka}$. Site BTB has $16 \mathrm{SST}$ dates that range from $9.4 \mathrm{ka}$ to $8.1 \mathrm{ka}$ and yield a mean and SD of $8.6 \pm 0.4 \mathrm{ka}$.

\section{Holocene Sand-Ramp Gullying and Shoreline Erosion}

Beaches and the seaward extents of Holocene sand ramps vary in terms of modern sand supply or depletion along the northern side of San Miguel Island. Beach erosion and the corresponding truncation of sand ramps predominate along the NW side of San Miguel, including the Castle Rock beaches between Point Bennett and Otter Point (Figures 12 and 13). The eroding sand ramps are truncated at the shoreline and are gullied by headward erosion to at least $100 \mathrm{~m}$ landward from the shoreline. In the north-central part of the island, between Otter Point and Harris Point, narrow beaches $(<50 \mathrm{~m}$ in across-shore width) transition to wider beaches (50-100 $\mathrm{m}$ in width) at the NE end of Simonton Cove. The sand ramps in Simonton Cove show decreasing gullying with increasing distance to the NE, suggesting more recent episodes of beach sand supply to the NE sand ramps in Simonton Cove. Both wide beaches ( $>100 \mathrm{~m}$ width) and the presence of foredunes linked to sand ramps occur at the eastern end of Cuyler Cove at the NE side of San Miguel. The large Holocene sand ramps at the eastern end of Cuyler Cover show no evidence of gullying by headward erosion, though deflation has locally oversteepened their midelevation (30-100 m elev.) slopes.

Modern littoral transport directions along the northern sides of San Miguel Island are interpreted from changes in shoreline orientations, beach widths, and nearshore sand shoals (Figure 13). Averaged winter significant wave heights $\left(H_{1 / 3}\right)$ of $1.5-3.5$ $\mathrm{m}$ and extreme storm waves to $7-8 \mathrm{~m}$ height generally approach the northern side of San Miguel Island from the NW. Mean wave direction from hourly recordings (mean $\sim 290^{\circ}$ TN) averaged for winter months (December/January/February [DJF]) for two years, 2014 and 2015, are from Santa Barbara Buoy LLNR 198 (NOAA, 2016). Wave refraction turns the nearshore waves to more shore-normal directions, splitting longshore transport to the SW and NE in the Castle Rock beaches and driving NE transport in Simonton Cove. Wave refraction around Harris Point reorients nearshore wave approach in Cuyler Cove, resulting in eastward littoral transport in Cuyler Cove. Littoral sand along the NE facing coast of San Miguel was transported south to feed the Cardwell Point spit/shoal at the SE end of San Miguel. Some sand either 
Table 2. Radiocarbon dated sand-ramp sequences in San Miguel Island.

\begin{tabular}{|c|c|c|c|c|c|c|c|c|}
\hline Locality/Site & Strat. & $\begin{array}{l}\text { Age } \\
(\mathrm{ka})\end{array}$ & Locality/Site & Strat. & $\begin{array}{l}\text { Age } \\
\text { (ka) }\end{array}$ & Locality/Site & Strat. & $\begin{array}{l}\text { Age } \\
\text { (ka) }\end{array}$ \\
\hline $\mathrm{SANM} / 3$ & PRB & 66 & $\mathrm{RPC} / 433$ & SST & 8.2 & $\mathrm{EBB} / 607 \mathrm{a}$ & SST & 8.2 \\
\hline $\mathrm{SANM} / 15$ & PRB & $>150$ & $\mathrm{HCC} / 467$ & HRS & 4.9 & $\mathrm{EBB} / 607 \mathrm{~b}$ & $\mathrm{SST}$ & 8.9 \\
\hline $\mathrm{ECH} / 9 \mathrm{a}$ & HRT & 0.5 & OTS/SM181 & PRS & 40 & BTB $/ 2 \mathrm{a}$ & SST & 8.3 \\
\hline $\mathrm{ECH} / 9 \mathrm{~b}$ & HRB & 5.2 & OTH/481a & HRT & 0.4 & $\mathrm{BTB} / 2 \mathrm{~b}$ & SST & 8.4 \\
\hline $\mathrm{EMC} / 87 \mathrm{a}$ & HRT & 2.4 & OTH/481b & HRT & 0.6 & $\mathrm{BTB} / / 2 \mathrm{a}$ & SST & 8.5 \\
\hline $\mathrm{EMC} / 87 \mathrm{~b}$ & HRT & 2.5 & OTH/481c & HRT & 1.0 & $\mathrm{BTB} / / 2 \mathrm{~b}$ & $\mathrm{SST}$ & 8.8 \\
\hline $\mathrm{EMC} / 87 \mathrm{c}$ & HRT & 2.6 & OTH/481d & HRT & 1.2 & BTB/3 & SST & 9.4 \\
\hline $\mathrm{EMC} / 87 \mathrm{~d}$ & HRT & 2.6 & $\mathrm{OTH} / 481 \mathrm{e}$ & HRT & 1.2 & $\mathrm{BTB} / 4 \mathrm{a}$ & SST & 8.1 \\
\hline EMC/87f & HRT & 2.8 & $\mathrm{OTH} / 481 \mathrm{f}$ & HRS & 1.3 & $\mathrm{BTB} / 4 \mathrm{~b}$ & SST & 8.2 \\
\hline $\mathrm{EMC} / 87 \mathrm{~g}$ & HRT & 3.0 & OTH/481g & HRT & 1.3 & BTB/5 & SST & 8.3 \\
\hline $\mathrm{EMC} / 87 \mathrm{~h}$ & HRT & 3.0 & OTH/481h & HRT & 1.3 & $\mathrm{BTB} / 606 \mathrm{a}$ & SST & 8.2 \\
\hline EMC/87i & HRT & 3.0 & $\mathrm{OTH} / 481 \mathrm{i}$ & HRS & 3.2 & $\mathrm{BTB} / 606 \mathrm{~b}$ & SST & 8.4 \\
\hline $\mathrm{EMC} / 87 \mathrm{j}$ & HRT & 3.1 & $\mathrm{OTH} / 481 \mathrm{j}$ & HRS & 3.7 & $\mathrm{BTB} / 606 \mathrm{c}$ & SST & 8.6 \\
\hline $\mathrm{EMC} / 87 \mathrm{k}$ & HRS & 4.0 & OTH/481k & HRS & 3.4 & BTB/606d & $\mathrm{SST}$ & 9.0 \\
\hline EMC/871 & HRS & 4.2 & OTH/481l & HRS & 3.9 & $\mathrm{BTB} / 606 \mathrm{e}$ & SST & 9.1 \\
\hline $\mathrm{EMC} / 87 \mathrm{~m}$ & HRS & 4.5 & $\mathrm{OTH} / 481 \mathrm{~m}$ & HRS & 5.7 & WBB/522a & SST & 9.0 \\
\hline $\mathrm{EMC} / 87 \mathrm{n}$ & HRS & 4.6 & OTH/481n & HRS & 5.9 & $\mathrm{WBB} / 522 \mathrm{~b}$ & HRB & 9.6 \\
\hline ECR/149 & HRT & 0.3 & OTH/481o & HRS & 6.0 & $\mathrm{WBB} / 522 \mathrm{c}$ & HRB & 9.8 \\
\hline ECR/152 & HRT & 2.7 & OTH/481p & SST & 6.5 & $\mathrm{WBB} / 522 \mathrm{~d}$ & HRB & 9.8 \\
\hline $\mathrm{ECR} / 161$ & HRS & 4.4 & $\mathrm{OTH} / 481 \mathrm{q}$ & SST & 7.2 & $\mathrm{ALP} / 525 \mathrm{a}$ & HRT & 0.5 \\
\hline ECR/163 & HRS & 2.9 & DYL/485 & HRT & 0.5 & $\mathrm{ALP} / 525 \mathrm{~b}$ & HRS & 1.2 \\
\hline ECR/166 & HRT & 2.3 & DYL/488 & HRS & 2.6 & $\mathrm{ALP} / 525 \mathrm{c}$ & HRS & 3.1 \\
\hline WCB/535 & HRS & 3.2 & HWS/467 & HRT & 1.3 & $\mathrm{ALP} / 525 \mathrm{~d}$ & HRS & 3.0 \\
\hline CDC/172 & HRB & 6.3 & OTC/605a & HRB & 6.3 & ALP/D525 & HRS & 1.7 \\
\hline SYH/SM186 & HRB & 6.2 & OTC/605b & HRB & 6.6 & LNR/528a & HRT & 1.2 \\
\hline SYH/SM187 & PHTC & 10.1 & OTC/605c & HRB & 6.4 & $\mathrm{LNR} / 528 \mathrm{~b}$ & HRT & 1.4 \\
\hline $\mathrm{LBH} / 350 \mathrm{a}$ & SST & 6.7 & OTC/605d & HRB & 6.6 & $\mathrm{LNR} / 528 \mathrm{c}$ & HRT & 1.4 \\
\hline $\mathrm{LBH} / 350 \mathrm{~b}$ & SST & 7.4 & OCT/605e & HRB & 6.7 & LNR/528d & HRT & 1.5 \\
\hline $\mathrm{LBH} / 350 \mathrm{c}$ & SST & 11.2 & BLC/AC1 & HRS & 3.4 & $\mathrm{LNR} / 528 \mathrm{e}$ & HRS & 4.8 \\
\hline BHR/SM172 & PRS & 21.5 & $\mathrm{ABP} / 503 \mathrm{a}$ & HRS & 5.5 & $\mathrm{LNR} / 528 \mathrm{f}$ & HRS & 5.8 \\
\hline ECL/SM171 & PRS & $>40$ & $\mathrm{ABP} / 503 \mathrm{~b}$ & HRT & 1.2 & PTB/SM177 & SSS & 17.4 \\
\hline CCC/SM174 & HRB & 6.6 & $\mathrm{ABP} / 503 \mathrm{c}$ & HRS & 2.3 & SHB/602a & HRS & 0.1 \\
\hline CCC/388 & HRB & 7.2 & $\mathrm{ABP} / 503 \mathrm{~d}$ & HRS & 2.5 & $\mathrm{SHB} / 602 \mathrm{~b}$ & HRS & 0.3 \\
\hline $\mathrm{CCN} / 438 \mathrm{a}$ & SST & 8.6 & $\mathrm{ABP} / 503 \mathrm{e}$ & HRS & 2.8 & $\mathrm{SHB} / 602 \mathrm{c}$ & HRS & 0.5 \\
\hline $\mathrm{CCN} / 438 \mathrm{~b}$ & SST & 10.6 & $\mathrm{ABP} / 504$ & HRS & 2.9 & $\mathrm{SHB} / 602 \mathrm{~d}$ & HRS & 0.5 \\
\hline YRD/179a & HRB & 7.9 & $\mathrm{ABP} / \mathrm{RSC} 1 \mathrm{a}$ & SST & 9.1 & FLF/SM131 & SSS & 14 \\
\hline YRD/SM180 & SSS & 18 & $\mathrm{ABP} / \mathrm{RCS} 1 \mathrm{~b}$ & SST & 9.4 & $\mathrm{LZP} / 520 \mathrm{a}$ & HRS & 3.6 \\
\hline YRDS/SM178 & SSB & 20.1 & BGD/510 & HRS & 1.2 & $\mathrm{LZP} / 520 \mathrm{~b}$ & HRS & 5.7 \\
\hline
\end{tabular}

The SANM dates are from TL dating (Peterson et al., 2006). SM designated sample number ages were derived from recalibrated radiocarbon dates from Johnson (1972). All other sample dates are from calibrated radiocarbon dates presented in Erlandson, Rick, and Peterson (2005). Details about, radiocarbon materials, calibrations, and laboratory identification numbers are provided in Erlandson, Rick, and Peterson (2005) and are summarized in Peterson et al. (2006). Site/sample position coordinates and sample positions (Strat) within the eolian deposits are also summarized in Peterson et al. (2006). Stratigraphic positions include Holocene sand-ramp top (HRT), Holocene sand-ramp bottom (HRB), Holocene sand-ramp internal strata (HRS), Pleistocene sand-ramp bottom (PRB), Pleistocene sand-ramp internal strata (PRS), Pleistocene sand-ramp top (PRT), Pleistocene hilltop sand caliche forest (PHTC), Simonton soil top (SST), and Simonton soil internal strata (SSS). The calibrated radiocarbon dated samples ( $\pm 1 \sigma)$ were converted to standardized dates (ka) by rounding to the nearest $0.1 \mathrm{ka}$. Sample locality position coordinates and elevations are shown in Table 1.

bypassed Abalone Point at the western side of San Miguel or crossed low inland topography to feed wide beaches and a small nearshore sand shoal, located just SE of Point Bennett. In summary, some littoral sand appears to have been lost from the northern coastline to the SE and SW ends of the island, thereby contributing to the apparent beach erosion and sand-ramp truncation along most of the northern coast of San Miguel.

\section{DISCUSSION}

In this section, the origins of coastal eolian sand ramps are related to island-shelf platform topography, changing paleo-sea levels, and paleo-wind/wave forcing of across-shelf sand supply to the northern side(s) of San Miguel Island. The destabilizations of Holocene sand ramps by erosive gullying, deflation, and slope failures are related to net losses of nearshore sand reserves in latest Holocene time. Truncated Holocene sand ramps are used as proxies to help predict potential beach erosion from future sea-level rise.

\section{Morpho-Stratigraphic Model of Sand-Ramp Development}

Twenty-five measured sections are plotted for elevation and easting position in two transects, northern and central, which extend along the west-east length $(\sim 13 \mathrm{~km})$ of San Miguel (Figure 14). The northern transect represents sand-ramp accretion against the northern slopes. Terraced bluff slopes along the northern side of San Miguel reach $0.5-1.0 \mathrm{~km}$ in landward width and $10-130 \mathrm{~m}$ in elevation. The central transect in San Miguel Island represents thinning of migratory sand/dune deposits and widespread loess deposition across the island hilltops. The central hilltop areas reach $3-5 \mathrm{~km}$ in width and $100-250 \mathrm{~m}$ in elevation. 


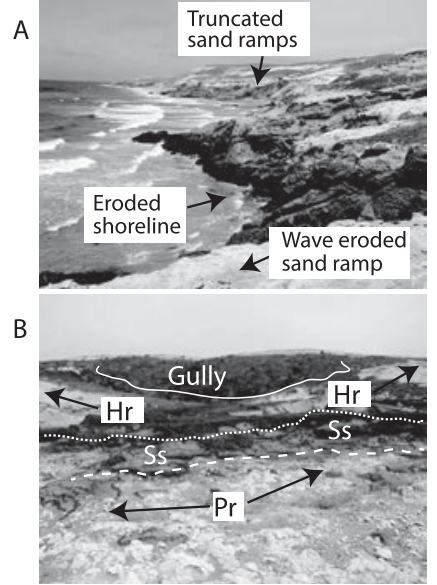

Figure 12. Part A: Eroded shoreline, near SANM18, showing narrow beaches and truncated sand ramps. The large Holocene sand ramps (photo background) are now beheaded in that they do not reach the beach sources of sand supply. Wave runup is also attacking the seaward extents of late Pleistocene sand ramps (photo foreground). Part B: Sea-cliff erosion (photo foreground) and headward gully/deflation trough erosion (photo background) of a sand-ramp sequence near SANM17, including (1) Holocene sand ramp (Hr) above the dotted line; (2) Simonton soil (Ss), about $0.5 \mathrm{~m}$ in vertical thickness, between the dotted and dashed lines; and (3) sand/caliche layer in a Pleistocene sand ramp (Pr) below the dashed line. View is up slope, to the south.

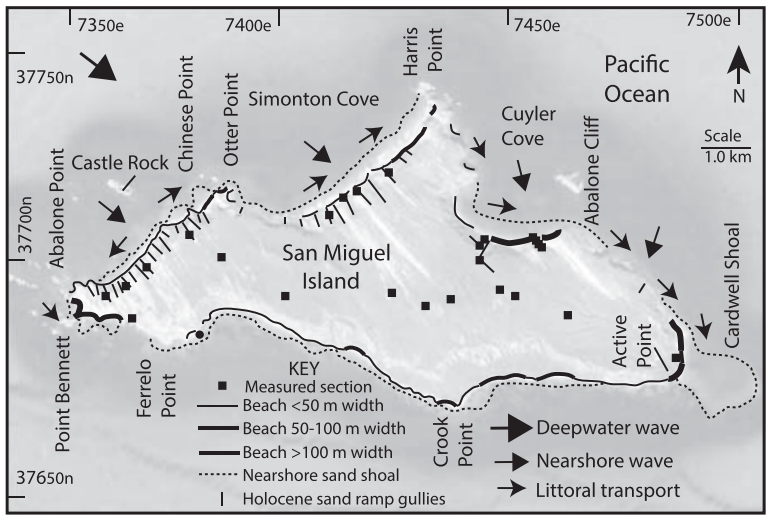

Figure 13. Map of modern shoreline beach widths and Holocene sand-ramp gullies/deflation troughs along the northern sides San Miguel Island. Deep water mean wave directions (MWDs) are averaged from hourly measurements for winter months (DJF) for two years, 2014 and 2015, to yield a bearing of $290^{\circ} \mathrm{TN}$. The data were downloaded from the Santa Barbara buoy LLNR 198 (Station 46054; DJF, 2014-2015) as reported online (NOAA 2016). Approximated nearshore wave directions are based on assumed refraction. Littoral transport directions are interpreted from alongshore changes in beach widths and nearshore sand shoal widths, relative to shoreline orientations. Beach widths are mapped for $<50 \mathrm{~m}$ width (erosional), 50-100 m width, and $>100 \mathrm{~m}$ width with incipient foredune development (stable or accreting). Apparent gullies/deflation troughs in Holocene sand ramps, of at least $100 \mathrm{~m}$ distance from the shoreline, are mapped for orientation and length (black lines). Measured sections (solid squares) are numbered in Figure 5.

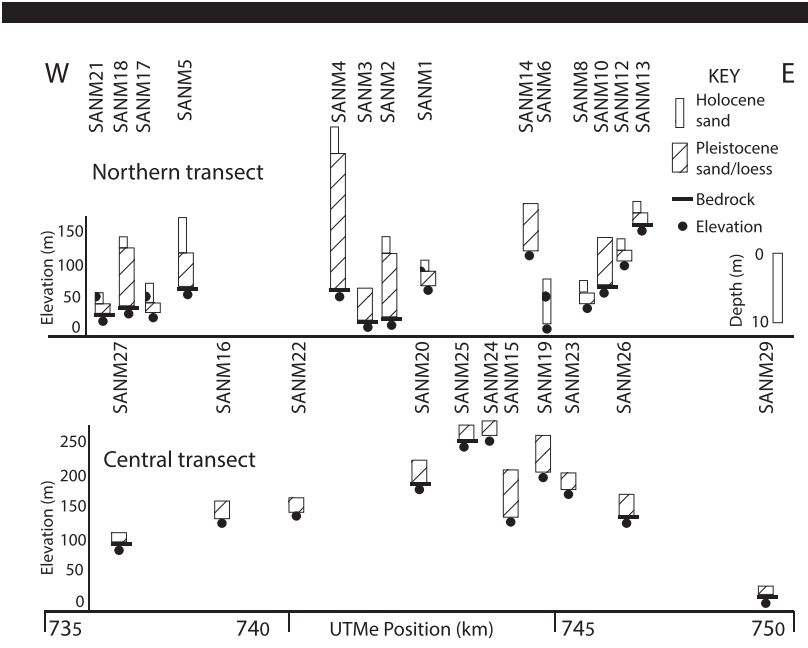

Figure 14. Stratigraphic sections from two west-east transects (northern and central) along San Miguel Island showing summarized eolian deposit ages (Holocene/Pleistocene), site elevations (m), and positions (UTM 10S eastings in $\mathrm{km}$ ). Remobilized sand deposits in the island highlands ( $>100 \mathrm{~m}$ elevation in the central transect) are shown as Pleistocene in age because of the presence of rounded peds from Pleistocene sand soils; however, some of the remobilized sand might have derived from windward Holocene sand ramps.

Two general relations are apparent from the morphostratigraphic development of the sand deposits in San Miguel Island. The Holocene sand-ramp deposits are generally much thinner than the late Pleistocene sand-ramp deposits. The thicker late Pleistocene sand-ramp deposits were likely derived from the long duration(s) of low-stand marine conditions (Figure 3A). Sand deposits in the emerged island-shelf platform were transported by eolian processes to the windward slopes of San Miguel Island, where sand ramps developed episodically for at least $150 \mathrm{ka}$ at SANM15 (Figures 5 and 8). Alluvial processes likely recycled some of the subaerial sand deposits back across the emerged shelf to low-stand beaches, thereby completing a cycle of sand supply on the isolated island-shelf platform.

A second general relation, that of restricted Holocene sandramp development, is attributed to the much shorter period of Holocene sand supply to the northern side of San Miguel during middle to late Holocene time (Table 2, Figure 3B). Specifically, Holocene sand-ramp deposits generally pinch out with increasing landward distance and/or increasing elevation on the northern slopes of San Miguel (Figure 14). The apparent migration of sand/dunes across the top of San Miguel Island during the mid-1900s was misleading, as much of the hilltop active sand supply was from the historic destabilization of vegetated late Pleistocene and Holocene sand-ramp and hilltop deposits (Rick, 2002). For the most part, the prehistoric Holocene sand ramps failed to reach the highest central hilltops, though they did cross the lower inland elevations of the eastern and western ends of San Miguel.

\section{Ages of Holocene Sand-Ramp Depositional Onset, Duration, and Termination}

Standardized dates $(\mathrm{ka})$ of samples collected from Holocene eolian deposit sites in San Miguel Island were analyzed for 
Table 3. Averaged dates of Holocene sand ramp and loess deposition in San Miguel Island.

\begin{tabular}{lcccc}
\hline \hline $\begin{array}{c}\text { Sand-Ramp } \\
\text { Age Parameters }\end{array}$ & $\begin{array}{c}\text { All Holocene } \\
\text { Ramp Tops (ka) }\end{array}$ & $\begin{array}{c}\text { All Holocene } \\
\text { Ramp Strata (ka) }\end{array}$ & $\begin{array}{c}\text { All Holocene } \\
\text { Ramp Bottoms (ka) }\end{array}$ & $\begin{array}{c}\text { All Simonton } \\
\text { Soil Tops (ka) }\end{array}$ \\
\hline Sample Number $(N)$ & 28 & 34 & 14 & 26 \\
Minimum age (ka) & 0.4 & 0.1 & 5.2 & 6.5 \\
Maximum age (ka) & 3.1 & 6.0 & 9.8 & 11.2 \\
Mean age (ka) & 1.7 & 3.4 & 7.2 & 8.6 \\
\pm 1 SD (ka) & 0.9 & 1.7 & 1.5 & 1.0 \\
\hline
\end{tabular}

Standardized ages ( $\mathrm{ka}$ ) data are from 102 radiocarbon dated samples from 29 sites in San Miguel Island. See Table 2 for relative stratigraphic positions and standardized dates of individual samples.

means and SDs $( \pm 1 \sigma)$ of four groups, as defined by relative stratigraphic positions (Table 3). The four stratigraphic position groups and associated mean ages include HRTs $(n=$ $28,1.7 \pm 0.9 \mathrm{ka}), \mathrm{HRSs}(n=34,3.4 \pm 1.7 \mathrm{ka}), \operatorname{HRBs}(n=14,7.2$ $\pm 1.5 \mathrm{ka})$, and SSTs $(n=26,8.6 \pm 1.0 \mathrm{ka})$. The mean ages of the four stratigraphic groups increase with relative depth. The mean onset of Holocene sand-ramp emplacement in San Miguel (7.2 ka) confirms the $\sim 7 \mathrm{ka}$ estimate that was proposed by Johnson (1972); however, the variation in sand-ramp bottom dates $( \pm 1 \sigma=1.5 \mathrm{ka})$ is substantial, though some of the variability is attributed to one anomalous site (WBB). The mean age of buried or inactive sand-ramp tops (1.7 ka) represents the widespread termination of sand supply to the windward slopes of San Miguel. Some of the currently active Holocene sand ramps are remnants of sand-ramp surfaces that were destabilized by historic live-stock grazing; however, the steeper active sand ramps (45\% grade) are experiencing downslope sand movement from ongoing sand-ramp deflation and slope steepening.

Estimated ages of Holocene sand-ramp development in 19 sites from the northern side of San Miguel Island are presented on the bases of dated sample stratigraphic positions (Figure 15). Multiple samples from similar stratigraphic positions are

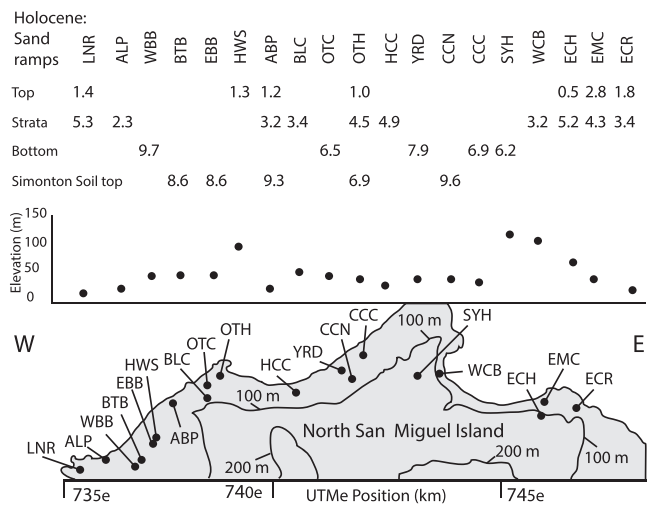

Figure 15. Standardized ages (ka) of stratigraphically grouped samples include sand-ramp top (Top), sand-ramp internal strata (Strata), and sandramp bottom (Bottom) for 19 northern slope sites in San Miguel Island (upper panel). Some of the ages are from single samples at corresponding sites, and other ages are from averages of multiple samples in a stratigraphic group from a single site. Elevations of the 19 sites (solid circles) range from 5 to $130 \mathrm{~m}$ (center panel). West-east positions of the 19 sites are shown along the northern side of San Miguel Island (lower panel). Elevation contours are at 100 and $200 \mathrm{~m}$. Site geographic data and standardized sample ages are from Tables 1 and 2 averaged for each site (Table 2). The site group ages are plotted against site east-west position (UTM easting) and site elevation (m). No apparent consistent trends occur between site internal strata ages (5.3-2.3 ka) and location or elevation. The youngest date $(0.5 \mathrm{ka})$ of terminated sand-ramp deposition (ramp top date) is from site ECH at the eastern end of Cuyler Cove. Wide beaches $(>100 \mathrm{~m})$ and incipient foredunes are locally developed at the eastern end of Cuyler Cove (Figure 13). The other six sites recording sand-ramp top dates range from $2.8 \mathrm{ka}$ to $1.0 \mathrm{ka}$. No consistent trends occur between the termination of sand-ramp deposition and elevation in the seven sites shown in Figure 15. The oldest sand-ramp bottom dates $(\sim 9.7 \mathrm{ka})$ are from one site: WBB. The next oldest sand-ramp site is YRD with a sand-ramp bottom date of $7.9 \mathrm{ka}$. That site together with three other sites from the middle-northern coastline of San Miguel, record sandramp bottom ages ranging from $7.9 \mathrm{ka}$ to $6.2 \mathrm{ka}$. There are no consistent relations between sand-ramp bottom ages and elevations of the sand ramps at sites OTC, YRD, CCC, and $\mathrm{SYH}$, from the middle-north side of San Miguel Island.

\section{Modeled Paleo-Wind and Wave Climate Forcing}

Modeled paleo-wind stress and deep-water wave directions (21-0 ka) off the coast of south-central California (Figure 1) are used to constrain interpretations of shelf-sand delivery to San Miguel Island during the MIS1 marine transgression. During the last glacial maximum (LGM) at 21-18 ka, the eustatic sea level dropped to $-130 \mathrm{~m}$ elevation (Figure 3A) with winterstorm wave base possibly extending to about $-150 \mathrm{~m}$ in the NW side of the island-shelf platform (Figure 4). Reeder, Rick, and Erlandson, (2011) have used paleogeographic arguments to estimate LGM sea level in the Channel Islands to $-110 \mathrm{~m}$. In either case, eustatic sea level had risen to within several meters of its present position by the latest Holocene time $(\leq 3 \mathrm{ka})$ (Figure 3B). Paleo-sea-level pressure gradients were downsampled from the GENMOM model (Alder and Hostetler, 2015), which combines the GENESISv3 atmospheric model (Alder et al., 2011) and the MOMv2 oceanic model (Pacanowski, 1996) to yield paleo-wind and wave stress vectors for the southcentral California coast region. The coupled GENMOM model outputs are verified at $0 \mathrm{ka}, 6 \mathrm{ka}$, and $21 \mathrm{ka}$ time intervals using terrestrial and oceanic climate data (Alder and Hostetler, 2015). The GENMOM model outputs are used to simulate seasonal surface-pressure equilibrium time slices at $3 \mathrm{ka}$ intervals for the last $21 \mathrm{ka}$ (Figure 16).

Modeled paleo-storm wind and wave stress conditions during the winter months (DJF) for the central part of the west coast of North America were maximized in the North Pacific Low Pressure Area (NPLPA), as defined for this article by the 995- 


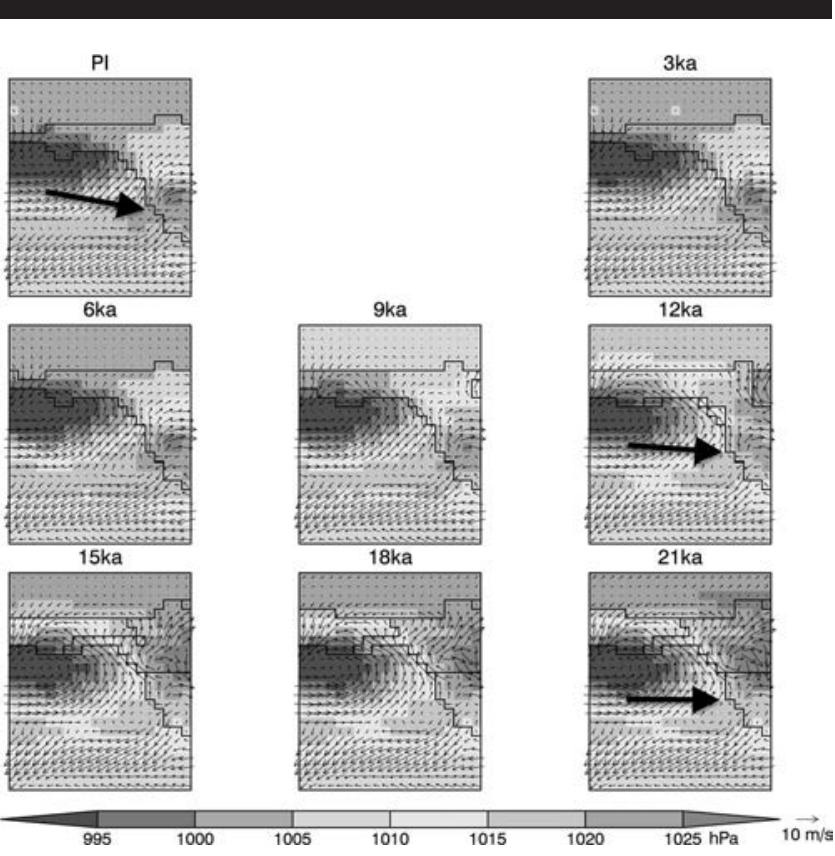

Figure 16. Paleo-wind and wave stress for the $0-21 \mathrm{ka}$ time interval for winter months (DJF). Surface pressure contours $(\mathrm{hPa})$ are used to establish pressure gradients that drive winds (arrow vectors). The minimum North Pacific Low Pressure Area (NPLPA), as defined here by the 995-1005 hpa contours, represents the winter storm center for the central part of the west coast of North America. Representative storm wave trajectories to San Miguel Island (large arrows) are shown for the 0, 12, and 21 ka time slices, with storm wave origins taken from the central positions of the $1005 \mathrm{hPa}$ pressure contour. Data for this figure were redrafted from Peterson et al. (2016), as initially sampled from Alder and Hostetler (2015).

$1005 \mathrm{hPa}$ surface-pressure contours (Figure 16). The modeled NPLPA storm center moved north and slightly east from late Pleistocene time to modern or pre-industrial time. The biggest change in the NPLPA position occurred between $12 \mathrm{ka}$ and $3 \mathrm{ka}$. These variations in the modeled position of the NPLPA potentially change the average storm-wave approach to a given coastline. For example, using the central $1005 \mathrm{hPa}$ contour at the southern boundary of the NPLPA as a common reference point, the estimated storm wave trajectory to San Miguel Island varies by $10-15^{\circ}$ (clockwise rotation) between $12 \mathrm{ka}$ and $3 \mathrm{ka}$. The relative changes in storm-wave directions in San Miguel were not as substantial as those that occurred further north along the central part of the west coast of North America (Peterson et al., 2007; Peterson et al., 2016). Modeled maximum surface-pressure gradients during winter months (DJF) are relatively similar between the late Pleistocene and late Holocene time slices, suggesting that winter-storm wave heights did not change substantially at San Miguel since the early Holocene time. Because of localized coastal surface-pressure gradients in the study region, local wind conditions in San Miguel Island are not interpreted from the regional paleo-climate data; however, the northern side of the island has been the windward side since the late Pleistocene time, as based on the abundances of both late Pleistocene and Holocene sand ramps there. Recent deflation troughs, remobilized linear dune ridges, and sand streamers in

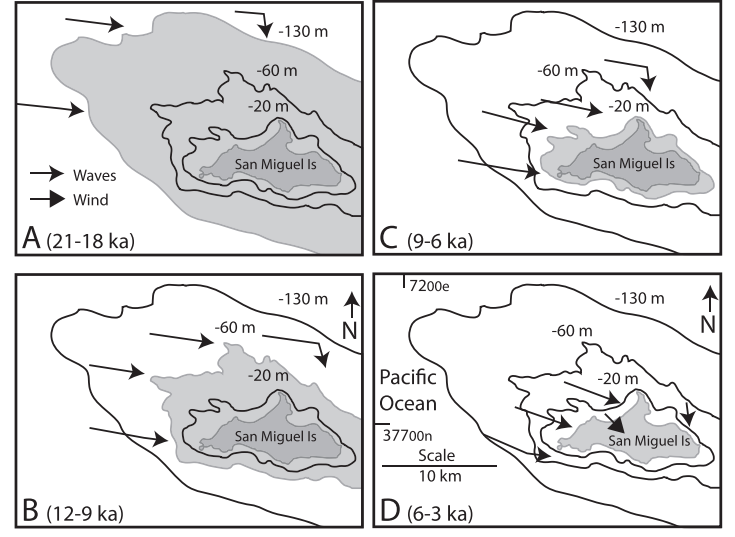

Figure 17. Diagrams of sea-level positions on island-shelf platform, winterwave direction and wind forcing (arrows), and associated shelf/beach sand supply to San Miguel Island during last glacial maximum (LGM) 21-18 ka, early Holocene transgression (12-9 ka), middle Holocene transgression (9-6 $\mathrm{ka}$ ), and late Holocene (6-3 ka). The elevation (shelf depth) contours correspond to the following eustatic sea-level curve ages of $-130 \mathrm{~m}$ (18-21 ka), $-60 \mathrm{~m}$ (11 ka), $-20 \mathrm{~m}$ (8 ka), and $0 \mathrm{~m}$ (present), as based on Figure 3B. Reeder et al. (2015) suggest maximum lowering to only $-110 \mathrm{~m}$. Paleo-wave directions are taken from the modern dominant winter-wave direction $\left(\sim 290^{\circ} \mathrm{TN}\right.$; Figure 13$)$ and progressively rotated counterclockwise $\left(3.5^{\circ}\right)$ for each successfully older interval based on the apparent shift in storm-wave trajectory between 3 and $15 \mathrm{ka}$ (Figure 16). Probable wave refraction is approximated for display purposes.

San Miguel (Figures 2 and 13) trend SE, reflecting dominant NW winds during late Holocene time.

\section{Latest Pleistocene and Holocene Model of Coastal Sand Supply}

During the LGM (21-18 ka), shorelines on the San Miguel Island-shelf platform reached maximum distances from the present San Miguel coastline (Figure 17). Episodic northern winds could have transported loess from the emerged shelf to supply the youngest Simonton soil loess internal strata (21-14 ka) across San Miguel (Table 2). It is not known whether the rapid fall in sea level corresponding to the LGM (Figure 3A) might have reduced eolian transport of sand to San Miguel. Such a reduction in eolian sand supply could conceivably have resulted from (1) increased distances of across-shelf eolian transport from the lowest stand beach-sand sources and/or (2) colonization of the recently emerged midshelf sand deposits by stabilizing vegetation. In any case, a hiatus in the Miguel Island sand supply appears to have left some Simonton soil strata unburied, as shown in measured sections SANM2, SANM4, SANM5, SANM8, SANM12, SANM17, and SANM18 (Figure 6 and 8), until the onset of sand-ramp deposition in the early-middle Holocene time. Following the LGM, a rapid rise of sea level during the early part of the MIS1 marine transgression (12-9 ka) submerged the lowest parts of the previously emerged shelf ( -130 to $-60 \mathrm{~m}$ elevation). The submergence would have terminated eolian transport of the lower shelf sediments, but it would also have initiated the shoreward movement of the pre-Holocene shelf sand deposits by oceanwave transport. 


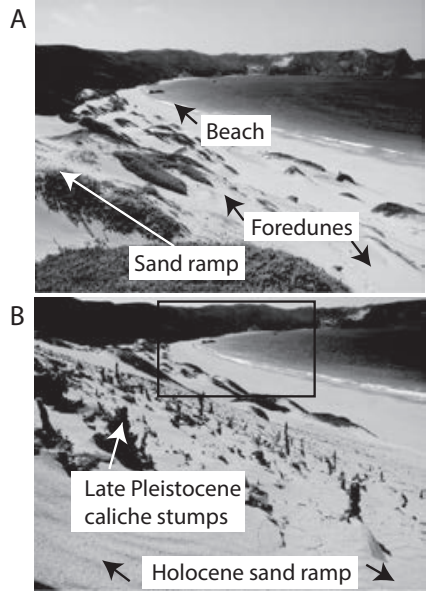

Figure 18. Part A: Wide beach and sand-ramp foredunes at the eastern end of Cuyler Cove (Figure 13) imply an abundant sand supply to the adjacent Holocene sand ramp(s) at the eastern end of San Miguel Island. Part B: The sand-ramp accretion (boxed inset shown in Part A), however, does not extend to the eroding Holocene sand ramp at $60 \mathrm{~m}$ elevation near measured section SANM10 (Figures 5 and 6). Eolian deflation and failure of the 45-55\% gradient sand ramps are thinning the Holocene sand cover, exposing the underlying late Pleistocene sand-ramp soils (Bk horizon), which include insitu caliche encrusted/replaced tree stumps or pipes (Grimes, 2004).

The earliest dated Holocene sand-ramp deposits (9.7 ka) in San Miguel are reported from WBB, located at the NW end of island, whereas the other Holocene sand-ramp sites in the middle-north coast yield onset ages of $\leq 7.9 \mathrm{ka}$ (Figure 15). Could the anomalous WBB site represent the onset of coastal sand supply from marine transgression? Throughout the latest Pleistocene and Holocene time, deep-water storm waves approached San Miguel Island from the W-NW (Figure 16). The oblique wave direction together with the steep inner-shelf gradient might account for the very early sand-ramp deposition at the NW end of San Miguel. The distance of marine transgression over the steeper NW end of the island at 12-9 ka (Figure 17B) would have been substantially shorter than over the middle-north inner shelf, possibly permitting earlier arrival of beach sand at the island's NW end. Additional work is needed to establish the earliest dates of coastal sand supply from marine transgression to the NW end of San Miguel. Between 9 ka and 6 $\mathrm{ka}$, the rates of sea-level rise decreased from $\geq 9 \mathrm{~m} \mathrm{ka}^{-1}$ to $\leq 4 \mathrm{~m}$ $\mathrm{ka}^{-1}$ (Figure 3B). Shoreward wave transport of inner-shelf sand deposits reached the middle-north side of San Miguel, leading to the widespread onset of Holocene sand-ramp deposition ( $~ 7.9$ to $\sim 6.2 \mathrm{ka}$ ) at sites OTC, YRD, CCC, and SYH (Figure 15). The SD of sand-ramp bottom dates in site OTH $(n=5,1 \sigma= \pm 0.16)$ is about an order of magnitude smaller than the SD of sand-ramp bottom dates from all sites ( $n=14,1 \sigma= \pm 1.5)$ (Tables 2 and 3). Between-site variability of sand-ramp bottom age is much greater than within-site variability. These relations suggest that local conditions of littoral transport, subaerial slope topography, and/or wind-field strengths influenced the timing of the earliest Holocene sand-ramp deposition on the windward side of San Miguel Island; however, a general similarity of sandramp bottom ages $(7.0 x \pm 0.8 \mathrm{ka})$ for the four dated sites from the middle-north coastline of San Miguel Island points to a critical initial period of surplus beach-sand supply. This initial period of surplus beach-sand supply to the middle-north side of San Miguel corresponds to the substantial slowing of the marine transgression during the 8-6 ka time interval. Net sand accretion in most of the sand ramps continued into the late Holocene time, as recorded by the mean and SD of all internal sand-ramp strata dates from San Miguel Island ( $n=34,3.4 \pm 1.7$ ka).

\section{Latest Holocene Beach Erosion, Sand-Ramp Truncation, and Gullying}

The mean and SD of sand-ramp top dates from dated sandramp sites in San Miguel Island ( $n=28,1.7 \pm 0.9 \mathrm{ka})$ generally represent the termination of sand-ramp accretion on the windward slopes of San Miguel (Table 3). Even the sand-ramp surfaces that are currently active, such as those at the eastern end of Cuyler Cove (Figures 13 and 18), are associated with net deflation and localized failures of over-steepened slopes. What caused the widespread cessation of sand-ramp deposition along the northern coastline of San Miguel in late Holocene time? Is the widespread termination of sand-ramp deposition connected to recent gullying and shoreline truncation of Holocene sand ramps along much of the northern coastline? These questions are addressed below in terms of late Holocene rates of marine transgression. There are at least two major concerns regarding future shoreline erosion in San Miguel. These are the ongoing and future losses of wide beach haul-out habitats for major pinniped rookeries (DeLong and Melin, 2002; Dugan et al., 2000; Stewart, 1984; Walker et al., 2002) and of coastal archaeological sites hosted in the vulnerable sand-ramp shorelines (Erlandson, 2008).

Under the near high-stand conditions of the late Holocene marine transgression, during the last $5 \mathrm{ka}$ (Figure 3B) onshore wave transport eroded available offshore sand deposits to the maximum depths of the winter wave base across the innermost shelf, located north of San Miguel Island (Figure 17). By the latest Holocene time ( $\leq 3 \mathrm{ka}$ ), the supply of shelf sand began to diminish, leading to the widespread termination of sand-ramp accretion $(\sim 1.7 \pm 0.9 \mathrm{ka})$ on the northern slopes of San Miguel. It is assumed that net sand losses from the littoral zone occurred during that time by one or more processes, leading to the present conditions of beach retreat and ocean-wave truncation of sand ramps (Figure 13). The processes of sand loss from the windward side of San Miguel could include (1) littoral transport around the western and eastern ends of San Miguel, (2) eolian transport of ramp sand either upslope or across the lower elevations of San Miguel, and/or (3) latest Holocene offshore sand transport following modest rates of sealevel rise $\left(1 \mathrm{~m} \mathrm{ka}^{-1}\right)$ during the last $3 \mathrm{ka}$ (Figure 19). Coring and dating of nearshore sand shoals at the SE and SW ends of San Miguel could help to constrain estimates of sand loss from alongshore littoral transport around the eastern and western ends of the island.

\section{Predicted Future Conditions of Sand-Ramp Stability/ Instability}

Two factors are likely to drive the future relative instability of Holocene sand-ramp deposits on the windward side of San Miguel Island. They include the ongoing gullying of unconsol- 


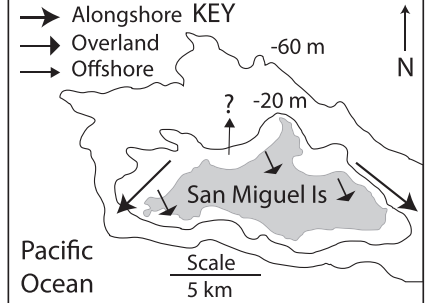

Figure 19. Losses of sand from the latest Holocene beaches and Holocene sand ramps could occur by alongshore transport around the island, overland transport across the island, and/or offshore transport following sea-level rise and a seaward shift in the across-shore profile (Bruun, 1962).

idated sand-ramp deposits and potential increases in the future rates of sea-level rise. The vegetative recolonization of eolian deposit surfaces in San Miguel Island has now reached $\geq 80 \%$ by relative surface area (Figure 13). The undercutting of gully headwalls and the progressive rilling and/or wind erosion of gully-side walls undermines archaeological and paleontological deposits and mixes differently aged materials in the sand-ramp gully colluvium (Figure 20A). The progressive gully erosion in the Holocene sand ramps extends into vegetated surfaces, so the ongoing vegetative recolonization of the sand ramps might reduce, but not eliminate, sand-ramp gully erosion in San Miguel.

The second major instability of the Holocene sand ramps in San Miguel occurs at the eroding northern shorelines. The truncated Holocene sand ramps become isolated from adjacent sources of beach sand supply when they no longer extend to their former beach and/or foredune sand sources. Truncated Holocene sand ramps might have some common origins with bluff-top dunes, cliff-top dunes, or perched dunes, as reported from other regions around the world (Arbogast, 2000; Hansen et al., 2010; Haslett, Davies, and Curr, 2000; Jackson and Nevin, 1992; Saye, Pye, and Clemmensen, 2006). For example, Haslett, Davies, and Curr (2000) report three stages of perched dune development in Brittany, France, including (1) onset of development at $\sim 4.5 \mathrm{ka}$, (2) stabilization, and (3) coastal erosion leading to truncation at a receding sea cliff. This model is somewhat similar to the sequence reported for the Holocene sand ramps in San Miguel, though only the first stage in Brittany was formally related to sea-level change conditions. In San Miguel Island, all three stages of sand-ramp evolution were influenced by changes in sea level and/or rates of sea-level change.

Along the northern side of San Miguel Island, the storm wave runup, eolian deflation, and pinniped haul-out activities further erode the exposed seaward faces of the truncated sand ramps (Figure 20B). The few remaining wide beaches $(>100 \mathrm{~m}$ width) and associated Holocene sand ramps, located at the NE end of Simonton Cove and at the eastern end of Cuyler Cove (Figure 13), are susceptible to future beach retreat. Such retreat is expected to accelerate from future increasing rates of sea-level rise associated with predicted global warming in the next century (Grinsted, Moore, and Jevrejeva, 2010; Rahmstorf, 2010; Vermeer and Rahmstorf, 2009). The current

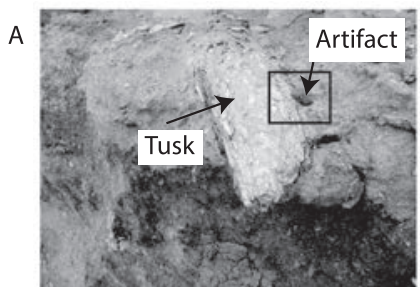

B

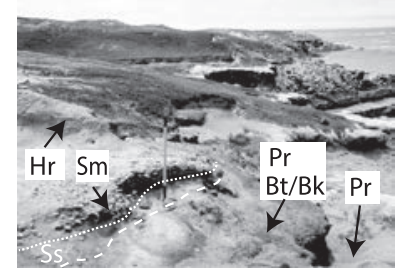

Figure 20. Part A: A worked stone tool (artifact) lying on top of a pygmy mammoth tusk ( $\sim 10 \mathrm{~cm}$ width), as preserved in a late Pleistocene sandramp-colluvium deposit near SANM17 (Erlandson, 2000). The artifact is not in in-situ context with the Pleistocene mammoth tusk (Agenbroad, 1998; Gray and Harz, 1998), but rather it fell down onto the tusk from an overlying 9-ka shell midden deposit in an actively eroding sand-ramp gully. Part B: Wave-runup eroded sand-ramp sequence showing (1) truncated Holocene sand ramp (Hr), overlying (2) an early Holocene shell midden (Sm), dated at $\sim 10 \mathrm{ka}$, overlying (3) a Simonton soil layer (Ss) between the dotted and dashed lines (white), overlying (4) late Pleistocene sand-ramp deposits (Pr) with a brown paleosol caliche horizon $(\mathrm{PdBt} / \mathrm{Bk})$. The eroding shoreline location in the photo is near the measured section SANM21. The yellow hoe handle is $1.0 \mathrm{~m}$ in height. View is to the west.

distribution of truncated sand ramps on the northern side of San Miguel indicates that littoral sand reserves are at a minimum and that the remaining active sand ramps will not survive future beach retreats of 100-150 m.

\section{CONGLUSIONS}

Sand ramps that developed along the northern side of San Miguel Island in the latest Pleistocene time and Holocene time record episodes of shelf sand supply to the northern side of the island by eolian across-shelf transport during marine low stands and by onshore wave transport across the inner shelf during the Holocene marine transgression. The Holocene sand ramps represent a relatively thin veneer over the thicker late Pleistocene sand-ramp deposits; however, the Holocene sandramp deposits locally thicken in abandoned gully troughs, topographic benches, and bluff tops. The current sand ramps generally lack large transverse or parabolic dune forms, reflecting past conditions of limited sand supply or recent conditions of deflation and slope failure.

The widespread onset of Holocene sand-ramp deposition occurred after the initial slowing of the marine transgression after $9 \mathrm{ka}$; however, sand-ramp bottom dates from the middlenorth coast vary by $\pm 0.9 \mathrm{ka}$, demonstrating localized influences on sand-ramp development from inner-shelf gradients, windward slope topography, and/or wind flow dynamics. The sand ramps continued to vertically accrete sand through late Holocene time but demonstrate a gradual termination of deposition in latest Holocene time $(\leq 3 \mathrm{ka})$. The termination of sand-ramp deposition was followed by sand-ramp erosion, 
including runoff gullying, eolian deflation, failures of oversteepened slopes, and truncation at retreating shorelines.

The sand ramps that were truncated at retreating sea cliffs are now cutoff from their previous sand sources, probably including pre-existing wide beaches and associated foredunes. The termination of surplus sand supply to the northern side of San Miguel Island is related to a nearly stationary zone of winter wave scouring in the innermost shelf during the late Holocene period of minimal sea-level rise. The widespread occurrences of truncated sand ramps in San Miguel represent evidence of disappearing nearshore sand reserves, which are being lost to alongshore, overland, and/or offshore sand sinks. The lack of continued shelf-sand supply to the northern shorelines in San Miguel in the latest Holocene time raises concern about the future existence of the remaining beaches and the shoreline sand-ramp deposits. Both are threatened by events of continued loss of nearshore sand reserves and potential future sea-level rise linked to predicted global warming. At stake in San Miguel Island are pinniped rookery haul-out beaches and numerous archaeological and paleontological sites located along the eroding coastline (Braje, 2010). The broader implications of truncated sand ramps in other marine coastlines around the world are that such features could foretell future losses of sanddepleted beaches in the event of accelerated sea-level rise from predicted future global warming. The use of recently truncated sand ramps to highlight local shoreline sensitivity to future losses of nearshore sand reserves have been underappreciated in the coastal research community.

\section{ACKNOWLEDGMENTS}

Charles Rosenfeld assisted with exposed sand-ramp section measurements and sampling for TL dating in San Miguel Island. David Percy assisted with sand-ramp site geo-referencing and measured section data-base compilations. Kennett Peterson assisted with initial manuscript editing. Field travel and TL dating support was provided by the NOAA Office of Sea Grant and Extramural Programs, U.S. Department of Commerce, under grant number NA76RG0476, project number R/ SD-04. Funds for ${ }^{14} \mathrm{C}$ dating of the San Miguel Island archaeological sites came from the National Science Foundation, the Foundation for Exploration and Research on Cultural Origins, the U.S. Navy, the National Park Service, and the University of Oregon. This paper is dedicated to the memory of Donald L. Johnson, who performed the pioneering work on dating sand-ramp/dune deposits in San Miguel Island.

\section{LITERATURE CITED}

Agenbroad, L.D., 1998. New pygmy mammoth (Mammuthus exilis) localities and radiocarbon dates from San Miguel, Santa Rosa, and Santa Cruz Islands, California. In: Weigand, R.W. (ed.), Contributions to the Geology of the Northern Channel Islands, Southern California. Bakersfield, California: American Association of Petroleum Geologists, pp. 169-175.

Alder, J.R. and Hostetler, S.W., 2015. Global climate simulations at 3000-year intervals for the last 21,000 years with the GENMOM coupled atmosphere-ocean model. Climate of the Past, 11, 449_471.

Alder, J.R.; Hostetler, S.W.; Pollard, D., and Schmittner, A., 2011. Evaluation of a present-day climate simulation with a new coupled atmosphere-ocean model GENMOM. Geoscience Model Development, 4, 69-83.
Anderson, R.S.; Starratt, S.; Brunner Jass, R.M., and Pinter, N., 2010. Fire and vegetation history on Santa Rosa Island, Channel Islands, and long-term environmental change in southern California. Journal of Quaternary Science, 25(5), 782-797.

Arbogast, A.F., 2000. Estimating the time since stabilization of a perched dune field along Lake Superior. Professional Geographer, 52(4), 594-606.

Bard, B.; Hamelin, R.G., and Fairbanks, R., 1990. U-Th obtained by mass spectrometry in corals from Barbados: Sea level during the past 130,000 years. Nature, 346(6283), 456-458.

Birkeland, P.W., 1999. Soils and Geomorphology. New York: Oxford University Press, 372p.

Braje, T.J., 2010. Modern Oceans, Ancient Sites: Archaeology and Marine Conservation on San Miguel Island, California. Salt Lake City: University of Utah Press, 176p.

Braje, T.J.; Erlandson, J.M., and Rick, T.C., 2013. Points in space and time: The distribution of Paleocoastal points and crescents on California's Northern Channel Islands. In: Jazwa, C. and Perry, J. (eds.), Small Islands, Big Implications: The California Channel Islands and Their Archaeological Contributions. Salt Lake City: University of Utah Press, pp. 72-106.

Bruun, P., 1962. Sea-level rise as a cause of shoreline erosion. Journal of Waterways Harbors Division, American Society of Civil Engineers, 88, 117-130.

Clark, J.; Mitrovica, J.X., and Alder, J., 2014. Coastal paleogeography of the California-Oregon-Washington and Bering Sea continenta shelves during the latest Pleistocene and Holocene: Implications for the archaeological record. Journal of Archaeological Science, 52, 12-23.

Cooper, W.S., 1967. Coastal Dunes of California (Geological Society of America, Memoir No. 104). Boulder: The Geological Society of America, 131p.

DeLong, R.L. and Melin, S.R., 2002. Thirty years of pinniped research at San Miguel Island. Proceedings of the 5th California Islands Symposium (Santa Barbara, California, Santa Barbara Museum of Natural History), pp. 401-406.

Dugan, J.E.; Hubbard, D.M.; Martin, D.L.; Engle, J.M.; Richards, D.M. Davis, G.E.; Lafferty, K.D., and Ambrose, R.F., 2000. Macrofauna communities of exposed sandy beaches on the Southern California mainland and Channel Islands. Proceedings of the 5th California Islands Symposium (Minerals Management Service Publication 2000 Ma). Santa Barbara, California, pp. 339-346.

Erlandson, J.M., 2000. A stratified association of mammoth remains and archaeological materials at Running Springs, San Miguel Island, California. Current Research in the Pleistocene, 17, 22.

Erlandson, J.M., 2008. Racing a rising tide: Global warming, rising seas, and the erosion of human history. Journal of Island and Coastal Archaeology, 3(2), 167-169.

Erlandson, J.M.; Kennett, D.J.; Ingram, B.L.; Guthrie, D.A.; Morris, D.P.; Tveskov, M.; West, G.J., and Walker, P.L., 1996. An archaeological and paleontological chronology for Daisy Cave (CA-SMI-261), San Miguel Island, California. Radiocarbon, 38(2), 355-373.

Erlandson, J.M. and Rick, T.C., 2002. A 9700-year-old shell midden on San Miguel Island, California. Antiquity, 76(292), 315-316.

Erlandson, J.M.; Rick, T.C.; Braje, T.J.; Casperson, M.; Culleton, B.J. Fulfrost, B.; Garcia, T.; Guthrie, D.A.; Jew, N.; Kennett, D.J.; Moss, M.L.; Reeder, L.; Skinner, C.; Watts, J., and Willis, L., 2011. Paleoindian seafaring, maritime technologies, and coastal foraging on California's Channel Islands. Science, 441(6021), 1181-1185.

Erlandson, J.M.; Rick, T.C., and Peterson, C.D., 2005. A geoarchaeological chronology of Holocene dune building on San Miguel Island, California. Holocene, 15(8), 1227-1235

Flemming, K.; Johnston, P.; Zwatz, D.; Yokoyama, Y.; Lambeck, K. and Chappell, J., 1998. Refining the eustatic sea-level curve since the last glacial maximum using far- and intermediate-field sites. Earth and Planetary Science Letters, 163(1), 327-342.

Gray, R.S. and Harz, W.H., 1998. Pygmy mammoths from San Miguel Island, California. In: Weigand, P.W. (ed.), Contributions to the Geology of the Northern Channel Islands, Southern California. Amsterdam: American Association of Petroleum Geologists, Pacific Section, MP 45, pp. 177-185. 
Grimes, K.G., 2004. Solution pipes or petrified forests? Drifting sands and drifting opinions. The Victorian Naturalist, 121(1), 14-22.

Grinsted, A.; Moore, J.C., and Jevrejeva, S., 2010. Reconstructing sea level from paleo and projected temperatures 200 to $2100 \mathrm{AD}$ Climate Dynamics, 34(4), 461-472.

Hansen, E.C.; Fisher, T.G.; Arbogast, A.F., and Bateman, M.D., 2010. Geomorphic history of low-perched, transgressive dune complexes along the southeastern shore of Lake Michigan. Aeolian Research, 1(10), 111-127.

Haslett, S.K.; Davies, P., and Curr, R.H.R., 2000. Geomorphologic and palaeoenvironmental development of Holocene perched coastal dune systems in Brittany, France. Geografiska Annaler: Series A, Physical Geography, 82(1), 79-88.

Jackson, D.W.T. and Nevin, G.H., 1992. Sand transport in a cliff top dune system at Fonte de Tejha, Portugal. In: Carter, R.G.W.; Curtis, T.G.F, and Sheehy-Skeffinton, M.J. (eds.), III European Dune Congress. Rotterdam: Balkema, pp. 81-92.

Johnson, D.L., 1972. Landscape Evolution on San Miguel Island, California. Lawrence, Kansas: University of Kansas, Ph.D. dissertation, 390p.

Knott, J.R. and Eley, D.S., 2006. Early to middle Holocene coastal dune and estuarine deposition, Santa Maria Valley, California. Physical Geography, 27(2), 127-136.

Meehl, G.A.; Stocker, T.F.; Collins, W.D.; Friedlingstein, P.; Gaye, A.T.; Gregory, J.M.; Kitoh, A.; Knutti, R.; Murphy, J.M.; Noda, A., and Raper, S.C., 2007. Global climate projections. Climate Change, 3495, 747-845.

Muhs, D.R.; Simmons, K.R.; Schumann, R.R.; Groves, L.T.; DeVogel, S.B.; Minor, S.A., and Laurel, D., 2014. Coastal tectonics on the eastern margin of the Pacific Rim: Late Quaternary sea-level history and uplift rates, Channel Islands National Park, California, USA. Quaternary Science Reviews, 105, 209-238.

Muhs, D.R.; Simmons, K.R.; Schumann, R.R.; Groves, L.T.; Mitrovica, J.X., and DeAnna, L., 2012. Sea-level history during the last interglacial complex on San Nicolas Island, California: Implications for glacial isostatic adjustment processes, paleozoogeography and tectonics. Quaternary Science Reviews, 37, 1-25.

Muhs, D.R.; Skipp, G.; Schumann, R.R.; Johnson, D.L.; McGeehin, J.P.; Beann, J.; Freeman, J.; Pearce, T.A., and Rowland, Z.M. 2009. The origin and paleoclimatic significance of carbonate sand dunes deposited on the California Channel Islands during the last glacial period. In: Damiani, C.C. and Garcelon, D.K. (eds.), Proceedings of the 7th California Islands Symposium (Arcata, California, Institute for Wildlife Studies), pp. 3-14.

National Oceanic and Atmospheric Administration (NOAA), 2016. National Data Buoy Center, Station 46054 (LLNR 198) West Santa Barbara, $38 \mathrm{~nm}$ west of Santa Barbara, California. http://www. ndbc.noaa.gov/.

Orme, A.R., 1992. Late Quaternary deposits near Point Sal, SouthCentral California: A time frame for coastal dune emplacement. In: Fletcher, C.H. and Wehmiller, J.F. (eds.), Quaternary Coasts of the United States: Marine and Lacustrine Systems, IGCP Project \#274. Tulsa, Oklahoma: Society for Sedimentary Geology, Special Publication No. 48, pp. 310-315.

Orr, P.C., 1968. Prehistory of Santa Rosa Island. Santa Barbara, California: Santa Barbara Museum of Natural History, 253p.

Pacanowski, R.C., 1996. MOM 2 Version 2.0 (Beta) Documentation: User's Guide and Reference Manual, Technical Report 3.2. Princeton, New Jersey: NOAA GFDL Ocean Group, GFDL, 329p.

Peterson, C.D.; Grathoff, G.H.; Reckendorf, F.; Percy, D., and Price, D.M., 2014. Late Pleistocene coastal loess deposits of the central west coast of North America: Terrestrial facies indicators for marine low-stand intervals. Aeolian Research, 12, 47-64.

Peterson, C.; Stock, E.; Cloyd, C.; Beckstrand, D.; Clough, C.; Erlandson, J.; Hart, R.; Murillo-Jiménez, J.; Percy, D.; Price, D.; Reckendorf, F., and Vanderburgh, S., 2006. Dating and Morphos- tratigraphy of Coastal Dune Sheets from the Central West Coast of North America. Corvallis, Oregon: Oregon Sea Grant Publications, $81 \mathrm{p}$.

Peterson, C.D.; Stock, E.; Meyer, J.; Kaijankoski, P., and Price, D.M., 2015. Origins of Quaternary coastal dune sheets in San Francisco and Monterey Bay, central California Coast, USA: Reflecting contrasts in shelf depocenters and coastal neotectonics. Journal of Coastal Research, 31(6), 1317-1333.

Peterson, C.D.; Stock, E.; Price, D.M; Hart, R.; Reckendorf, F.; Erlandson, J.M., and Hostetler, S.W., 2007. Ages, distributions, and origins of upland coastal dune sheets in Oregon, USA. Geomorphology, 91(1), 81-102.

Peterson, C.D.; Twichell, D.C.; Roberts, M.C.; Vanderburgh, S., and Hostetler, S.W., 2016. Accommodation space in a high-wave-energy inner-shelf during the Holocene marine transgression: Correlation of onshore and offshore inner-shelf deposits (0-12 ka) in the Columbia River littoral cell system, Washington and Oregon, USA. Marine Geology, 379, 140-156.

Peterson, C.D.; Vanderburgh, S.; Roberts M.C.; Jol, H.M.; Phipps, J.P., and Twichell, D.C., 2010. Composition, age, and depositional rates of Holocene shoreface deposits under barriers and beach plains of the Columbia River littoral cell, USA. Marine Geology, 273(1), 62-82.

Rahmstorf, S., 2007. A semi-empirical approach to projecting future sea-level rise. Science, 315(5810), 368-370.

Rahmstorf, S., 2010. A new view on sea level rise. Nature Reports Climate Change, 44-45. doi:10.1038/climate.2010.29

Reeder, L.A.; Rick, T.C., and Erlandson, J.M., 2011. Our disappearing past: A GIS analysis of the vulnerability of coastal archaeological resources in California's Santa Barbara Channel region. Journal of Coastal Conservation, 16.2, 187-197.

Reeder-Myers, L.; Elandson, J.M.; Muhs, D.R., and Rick, T.C., 2015. Sea level, paleogeography, and archeology on California's Northern Channel Islands. Quaternary Research, 83(2), 263-272.

Rick, T.C., 2002. Eolian processes, ground cover, and the archaeology of coastal dunes: A taphonomic case study from San Miguel Island, California, U.S.A. Geoarchaeology, 17(8), 811-833.

Rick, T.C.; Erlandson, J.M., and Vellanoweth, R.L., 2006. Taphonomy and site formation processes on California's Northern Channel Islands. Geoarchaeology, 21(6), 567-589.

Rick, T.C.; Erlandson, J.M.; Vellanoweth, R.L.; Braie, T.J.; Collins, P.W.; Guthrie, D.A., and Stafford, T.W., 2009. The origins and antiquity of the island fox (Urocyon littoralis): AMS C14 dates from California's Channel Islands. Quaternary Research, 7, 93-98.

Saye, S.E.; Pye K., and Clemmensen, LB., 2006. Development of a cliff-top dune indicated by particle size and geochemical characteristics: Rubjerg Knude, Denmark. Sedimentology, 53(1), 1-21.

Sorlien, C.C., 1994. Faulting and uplift of the Northern Channel Islands, California. In: Halvorson W.L. and Maender, G.J. (eds.), The Fourth California Islands Symposium: Update on the Status of Resources. Santa Barbara, California: Santa Barbara Museum of Natural History, pp. 281-297.

Stewart, B.S., 1984. Diurnal hauling patterns of harbor seals at San Miguel Island, California. The Journal of Wildlife Management, 48(4), 1459-1461.

Vermeer, M. and Rahmstorf, S., 2009. Global sea level linked to global temperature. Proceedings of the National Academy of Sciences, 106(51), 21527-21532.

Walker, P.L.; Kennett, D.J.; Jones, T.L., and DeLong, R., 2002 Archaeological investigations at the Point Bennett pinniped rookery on San Miguel Island. Proceedings of the 5th California Islands Symposium. Santa Barbara, California: Santa Barbara Museum of Natural History, pp. 628-632.

West, G.M. and Erlandson, J.M., 1994. A late Pleistocene pollen record from San Miguel Island, California: Preliminary results. American Quaternary Association Program and Abstracts, 13, 256. 